\title{
LAS FRONTERAS POROSAS DE LAS GUERRAS DE INDEPENDENCIA: EL ARMISTICIO DE TRUJILLO EN LAS PROVINCIAS DE LA REGIÓN CARIBE COLOMBIANA, 1820-1821
}

\author{
Roger Pita Pico ${ }^{1}$ \\ Academia Colombiana de Historia \\ DOI: 10.17533/udea.tempus.n7a02
}

\section{Resumen}

En el marco de la conmemoración del Bicentenario de la Independencia, este artículo analiza el proceso de delimitación de territorios y cese al fuego decretado por el armisticio de Trujillo y las complicaciones que giraron en torno a su aplicación en las provincias de la región Caribe colombiana. Varias dificultades precipitaron la terminación del acuerdo. Aunque finalmente no se desarrollaron las negociaciones de paz, el armisticio marcó un punto de ruptura en las guerras de Independencia pues los españoles reconocieron la causa republicana como un proceso de emancipación nacional mientras que los patriotas fortalecieron sus tropas y lograron pocos meses después la liberación de Cartagena y de toda la región Caribe.

Palabras clave: tratado, armisticio, guerras, Independencia, región Caribe, Colombia, siglo XIX.

\begin{abstract}
Within the framework of the commemoration of the Bicentennial of Independence, this article analyzes the process of delimitation of territories and ceasefire decreed by the Trujillo armistice and the complications that revolved around its application in the provinces of the Colombian Caribbean region. Several difficulties precipitated the termination of the agreement. Although the peace negotiations did not finally take place, the armistice marked a point of rupture in the wars of Independence as the Spaniards recognized the republican cause as a process of national emancipation while the patriots strengthened their troops and succeeded a few months after the liberation of Cartagena and the entire Caribbean region.
\end{abstract}

\footnotetext{
${ }^{1}$ Magíster en Estudios Políticos de la Pontificia Universidad Javeriana. Especialista en Política Social. Politólogo de la Universidad de los Andes. Miembro de Número de la Academia Colombiana de Historia. Director de la Biblioteca Eduardo Santos. de la Academia Colombiana de Historia. Correo electrónico: rogpitc@ hotmail.com.
} 
Roger Pita Pico

Key words: treaty, armistice, war, Independence, Caribbean Region, Colombia, XIX century.

\section{Introducción}

La crisis política iniciada en España en 1808 tras la prisión del Rey Fernando VII y la invasión de los franceses generó un vacío en el poder y marcó el inicio del período revolucionario experimentado en los dominios hispanoamericanos.

El proceso de Independencia en la Nueva Granada se inauguró en 1810 con la etapa conocida como la Primera República Federativa, tiempo durante el cual la región Caribe fue escenario de una álgida confrontación regional entre la provincia de Cartagena que desde muy temprano se mostró proclive al proyecto independentista y la colindante provincia de Santa Marta que se erigió como un bastión de la resistencia monárquica. Derrotados los militares franceses en la península ibérica, Fernando VII restituyó en 1814 el Absolutismo y se dio a la tarea de reintegrar su Imperio para lo cual impartió orden de reconquistar por la vía militar las colonias americanas que habían declarado su independencia. Para cumplir ese derrotero, se envió desde la metrópoli un fuerte ejército liderado por el comandante Pablo Morillo, cuyo primer objetivo fue someter a la plaza de Cartagena, lo cual le abrió el camino para la vertiginosa recuperación del resto del territorio neogranadino y la restauración del sistema monárquico durante el lapso de cuatro años.

Después de la victoria obtenida en la batalla de Boyacá el 7 de agosto de 1819, las tropas republicanas emprendieron un largo y complicado proceso con miras a recobrar la totalidad del territorio de la Nueva Granada. A principios de 1820, luego de haber ocupado la zona central, la franja nororiental y la provincia de Antioquia, los esfuerzos se concentraron en liberar la cuenca baja del río Magdalena y la región Caribe para lo cual se delegó el mando militar de las operaciones al coronel Mariano Montilla, quien contó con el apoyo de los oficiales José María Córdova, Jacinto Lara, José María Carreño, Hermógenes Maza, Luis Brión y José Prudencio Padilla. Córdova y Maza se movilizaron hacia la población ribereña de Tenerife, operación que les permitió controlar el río Magdalena. En junio Brión logró desembarcar junto con la legión irlandesa en su intención 
por expulsar a los realistas de Riohacha. Entre tanto, el coronel Montilla reorganizó sus huestes y logró liberar a Santa Marta en el mes de noviembre².

Pese a estos avances, hacia finales de este año la lucha militar seguía desenfrenadamente. Los españoles defendían con ahínco su último bastión en la región costera: la plaza de Cartagena. Montilla mantenía cercada por tierra esta ciudad amurallada desde el $1^{\circ}$ de julio ${ }^{3}$ mientras que Padilla hacía lo propio por vía marítima.

En esta coyuntura el balance de fuerzas parecía inclinarse a favor del bando patriota. Se observaba ya un desgaste ante la prolongación e inclemencia de una guerra que había iniciado hacía poco más de una década. No muy lejano estaba el recuerdo del periodo de guerra a muerte ${ }^{4}$ y del funesto sitio de más de 100 días impuesto en 1815 por los españoles en Cartagena que había dejado un considerable número de víctimas ${ }^{5}$. Este cúmulo de circunstancias persuadió a varios sectores del imperativo de pensar seriamente en buscar una pronta solución pacífica a este conflicto.

No obstante lo anterior, la tendencia conciliadora que surgió a partir de 1820 en el mundo hispanoamericano no debe entenderse unívocamente como una manifestación espontánea surgida en estos territorios sino que resulta necesario conectarla con el contexto externo y las consecuencias derivadas de los sucesos ocurridos en España. Bastante convulsionado había comenzado el año en esta península. Después del levantamiento de Riego, fueron convocadas las Cortes y se restableció la Constitución de Cádiz a la cual el Rey Fernando VII elevó su juramento. Las Cortes manifestaron su intención de restaurar el dominio español en América a través de una amnistía general, para lo cual se mostraron dispuestas a hacer concesiones prometiendo a las fuerzas insurgentes que conservarían el poder de las provincias que hubiesen conquistado pero con la condición de que

\footnotetext{
2 Adelaida Sourdís Nájera, "Ruptura del Estado colonial y tránsito hacia la República 1800-1850", en Historia económica y social del Caribe colombiano, Eds. Adolfo Meisel Roca (Bogotá: Ediciones Uninorte-Ecoe Ediciones, 1994), 181-189.

${ }^{3}$ Según relató el teniente coronel de la artillería española Ignacio Romero Cepeda, por estos días la guarnición española que defendía la plaza contaba con 600 hombres del Regimiento de León, 300 del batallón del Rey y Valencia, 150 de la Artillería veterana y 100 milicianos pardos, para un total de 1.150 hombres y 255 cañones. En términos comparativos, las fuerzas republicanas superaban ya estas cifras pues contaban con 2.000 hombres en tierra y 500 integrantes de las fuerzas sutiles. José María de Mier, Homenaje a José Padilla en el año del sesquicentenario de la batalla naval de Maracaibo (Bogotá: Editorial Kelly, 1973), 10.

${ }^{4}$ Decreto promulgado por el oficial Simón Bolívar en la población venezolana de Trujillo el 15 de junio de 1813. Fue una declaratoria que se planteó como reacción a las continuas violaciones al derecho de gentes por parte de los españoles.

${ }^{5}$ Rodolfo Segovia Salas. 105 días. El Sitio de Pablo Morillo a Cartagena de Indias (Bogotá: El Áncora, 2007).
} 
estas debían depender de España ${ }^{6}$. Implícitamente este trascendental paso indicaba que de alguna forma los españoles reconocían haber perdido progresivamente su poderío mientras los republicanos obtenían éxitos continuos en su ofensiva militar.

El comandante español Pablo Morillo recibió instrucciones para dar comienzo a los acercamientos de paz y así lo comunicó al Congreso de Angostura ${ }^{7}$ que, tras varias deliberaciones, finalmente decidió el 11 de julio buscar conjuntamente la paz pero con la condición de que solo se sentarían a negociar sobre la base del reconocimiento de la soberanía e independencia de Colombia ${ }^{8}$. Esta última exigencia desconcertó a los españoles y aplazó por un tiempo el acuerdo.

Pese a estos tempranos reparos, muy pronto esa oleada de ánimos conciliatorios se extendió a las provincias en conflicto bajo la iniciativa de los españoles de lograr avances finiquitando acuerdos a nivel territorial. Así se formalizó a través de sendas cartas en las cuales el comandante Morillo impartió instrucciones sobre este asunto al virrey Juan Sámano, al gobernador español de Santa Marta don Pedro Ruíz de Porras y al gobernador español de Cartagena don Gabriel de Torres.

En desarrollo de estas orientaciones superiores, el primero en hacer proposiciones conciliatorias fue el gobernador de Santa Marta a través de una comunicación que enviara el 18 de julio al coronel republicano Mariano Montilla, comandante en jefe de las fuerzas republicanas combinadas que actuaban en la Costa Caribe colombiana, a quien le propuso una amnistía por el término de un mes. Sin embargo, este oficial rechazó el ofrecimiento en razón a la orden superior que había recibido en el sentido de no entrar en conversaciones sin exigir primero el reconocimiento de la Independencia de estos territorios americanos ${ }^{9}$.

En la colindante provincia de Cartagena, el gobernador español de la plaza envió el 20 de julio una carta al general Bolívar en la que planteaba una suspensión de armas para tratar sobre la posibilidad de una vía negociada en aras de una España unida y poderosa, para lo cual se mostró

${ }^{6}$ Academia Colombiana de Historia, Fondo Archivo del General Miguel de la Torre, tomo I, 112-116.

${ }^{7}$ Simón B. O'Leary, Memorias del General O'Leary, tomo XVII (Caracas: Imprenta de la Gaceta Oficial, 1983 ), 278.

${ }^{8}$ Actas del Congreso de Angostura 1819-1820 (Bogotá: Biblioteca de la Presidencia de la República, 1988 ), 353.

${ }^{9}$ Biblioteca Nacional de Colombia (BNC), Fondo Archivo Histórico Restrepo, Fondo I, Vol. 15, pieza 5, ff. 133r, 140 r. 
en plena disposición de abrir diálogos por medio de diputados aunque se abrió también la opción de entenderse directamente con la Corte de España ${ }^{10}$.

Mientras el Libertador Simón Bolívar se mantenía al tanto de estos acercamientos, al mismo tiempo se concentraba en sus planes estratégicos de guerra para ganar cada vez más terreno. Dentro de ese propósito, dejó temporalmente su cuartel general en la frontera con Venezuela para dirigirse a la Costa Norte colombiana con la intención de supervisar directamente el procedimiento a seguir para acentuar el sitio sobre Cartagena. Días atrás, el almirante Luis Brión le había hecho saber que, en esos momentos en que había esperanzas de reconquistar el puerto de Santa Marta, no era conveniente pensar en el armisticio sino por el contrario aprovechar que la tropa estaba lista para emprender una gran ofensiva ${ }^{11}$.

Desde la población de Barranquilla y, casi un mes después de que Torres lanzara su propuesta de reconciliación, Bolívar finalmente contestó expresando su voluntad de tratar sobre estos temas para lo cual apeló a la necesidad de convocar a un armisticio como fase preliminar para arreglar los otros puntos pendientes ${ }^{12}$. Sin embargo, la respuesta del gobernador fue muy enfática en el sentido de que nada se podía adelantar si el gobierno republicano no contestaba previamente de manera categórica a la invitación de someterse a España, jurar la Constitución y enviar diputados a las Cortes. El modo en que estos tres condicionantes debían concretarse, las garantías y la discusión en torno a las dudas que pudieran suscitarse, serían tratados en la referida tregua ${ }^{13}$.

Airada fue la reacción del Libertador frente a las pretensiones del brigadier español ${ }^{14}$ e igual de incendiaria fue la respuesta del gobernador a través de una proclama difundida a su tropa ${ }^{15}$. Ante este malogrado intento de diálogo, el gobernador ordenó un ataque militar sobre el cuartel general republicano de Turbaco, en el intento por capturar sorpresivamente a Bolívar quien al final de todo logró salvarse pues apenas hacía dos días había viajado hacia el interior del departamento de Cundinamarca. Más de 400 soldados españoles del Regimiento de León bajo las órdenes del

\footnotetext{
${ }^{10}$ Manuel Ezequiel Corrales, Documentos para la historia de la provincia de Cartagena de Indias, tomo 2 (Bogotá: Imprenta de Medardo Rivas, 1883), tomo 2, 410-411.

${ }^{11}$ Archivo General de la Nación (AGN), Sección República, Fondo Secretaría de Guerra y Marina, tomo 325, f. 422v.

12 Manuel Ezequiel Corrales, Documentos para la historia, tomo 2, 414-415.

${ }^{13}$ Manuel Ezequiel Corrales, Documentos para la historia, tomo 2, 415.

${ }^{14}$ Guillermo Plazas Olarte, "Historia Militar", en: Historia Extensa de Colombia, Vol. XVIII, tomo III (Bogotá: Ediciones Lerner, 1970), 93.

${ }^{15}$ Manuel Ezequiel Corrales, Documentos para la historia, tomo II, 418.
} 
coronel Miguel Valbuena lanzaron el 10 de septiembre una recia ofensiva contra los 650 militares que defendían Turbaco. Los españoles incendiaron el pueblo y arremetieron sin clemencia ${ }^{16}$. Paradójicamente, la ambivalencia reinante en esta coyuntura se vio reflejada en el escudo que la alta oficialidad española ordenó entregar a los oficiales más destacados de esta acción militar, el cual tenía en su parte inferior una espada y un ramo de oliva cruzado "[...] significando el deseo que la nación tiene de hacer la paz y la necesidad de hacer la guerra por la obstinación de los enemigos"17.

Ante este y otros tantos incidentes, Morillo entabló contacto directo con el presidente Simón Bolívar quien el 21 de septiembre, desde su cuartel general de San Cristóbal, decidió finalmente dialogar en aras de la paz aun sabiendo que esto significaría algunos sacrificios a los progresos conseguidos en el campo de batalla ${ }^{18}$. Pero, por otro lado, veían los republicanos en este tiempo de tregua una oportunidad propicia para robustecer su ejército e incrementar la adhesión popular en favor de la causa independentista.

Mientras Bolívar se inclinaba por esta decisión conciliadora, paralelamente dictaba órdenes a sus comandantes apostados en la Costa Norte para que aceleraran sus operaciones con miras a conquistar la plaza de Santa Marta, objetivo que se concretó a finales del mes de octubre.

Antes de sentarse a negociar, el principal punto de desacuerdo era la ciudad de Maracaibo ubicada al noroeste de Venezuela pues Bolívar esperaba que antes de la firma sus tropas ocuparan este centro estratégico ${ }^{19}$ pero, como finalmente no se logró, terminó cediéndolo. Para el mes de noviembre esta y otras diferencias fueron disipadas y ambos gobiernos nombraron sus comisionados. Los del bando republicano fueron el general Antonio José de Sucre, el coronel Pedro Briceño Méndez y el teniente coronel José Gabriel Pérez. Por el lado español, las negociaciones

\footnotetext{
${ }^{16}$ Manuel Ezequiel Corrales, Efemérides y Anales del Estado de Bolívar (Bogotá: Casa Editorial de J. J. Pérez, 1889), tomo II, 311-316.

${ }^{17}$ Gabriel de Torres y Velasco, Órdenes militares del último gobernador español en Cartagena de Indias 1820-1821 (Bogotá: Litografía Arco, 1986), 36.

18 José Manuel Restrepo, Documentos importantes para la historia de la Revolución de la República de Colombia en la América Meridional (Medellín: Universidad de Antioquia-Universidad Nacional, 2009, CD), 699.

${ }^{19} \mathrm{La}$ importancia militar de esta ciudad estribaba en el hecho de que permitía una salida al mar, facilitaba el movimiento de tropas desde la costa colombiana hacia Venezuela y era un punto clave de conexión con los valles de Cúcuta que era la sede del cuartel general del Libertador y sede del próximo Congreso.
} 
estuvieron a cargo del general Ramón Correa, el alcalde de Caracas don Juan Rodríguez Toro y don Francisco González de Linares.

Luego de tres días de discusiones, el acuerdo fue finalmente firmado a las diez de la noche del 25 de noviembre en la ciudad de Trujillo y refrendado a los dos días en el célebre encuentro amistoso entre Bolívar y Morillo en la población de Santa $\mathrm{Ana}^{20}$. En el encabezado del documento ambos gobiernos expresaron su voluntad de superar las discordias, para lo cual había que dar un paso crucial que era la suspensión de las operaciones militares "para poderse entender y explicar". La tregua se fijó durante el lapso de seis meses contados desde el momento en que se comunicara la ratificación de este convenio. No obstante, bajo el principio de la buena fe y de los deseos "sinceros" de fenecer la guerra, el cese podía prorrogarse por el tiempo que fuese necesario mientras concluían las negociaciones.

Las tropas de uno y otro ejército debían permanecer en las posiciones que ocuparan al momento de notificarles la suspensión de hostilidades, para lo cual era imprescindible señalar límites "claros y bien conocidos". Para el caso del conflicto vivido en Venezuela se acordaron previamente los límites. Para las demás provincias en disputa, la del Cauca y las de la región Caribe colombiana, había que nombrar comisionados especiales para que se llegara a un arreglo "amigable".

Previendo el hecho de que, al momento de comunicado el tratado, se hallaran dentro de los límites de demarcación algunas tropas o guerrillas enemigas que no debían permanecer en el territorio, se les permitiría retirarse fuera de la línea de demarcación y unirse al ejército a que estaban adscritas sin haber lugar a ningún tipo de seducción que promoviera el cambio de bando. Si se llegaba a romper el armisticio, no podían reabrirse las hostilidades sin el previo aviso al adversario cuarenta días antes de que se ejecutara el primer acto de hostilidad.

Con el fin de brindar un testimonio de los principios "filantrópicos" que inspiraron a ambos gobiernos para exterminar los excesos y horrores que habían caracterizado esta guerra ${ }^{21}$, se

20 Jorge Mercado, Campaña de invasión del teniente general don Pablo Morillo 1815-1816 (Bogotá: Editorial Iris, 1963), 430-433.

${ }^{21}$ Entre las fases más violentas de las guerras de Independencia, no hay que olvidar la guerra a muerte declarada a mediados de 1813 en Venezuela por Bolívar, en reacción a las continuas violaciones al derecho de gentes por parte de los españoles. 
comprometieron a firmar también en esos momentos un tratado de regularización de la guerra conforme al derecho de gentes y "a las prácticas más liberales, sabias y humanas de las naciones civilizadas" $" 22$.

Era claro que el acuerdo no se hacía efectivo hasta tanto los oficiales en campaña no fuesen notificados oficialmente por sus superiores. Es por ello que una estrategia usual utilizada por los bandos contendientes fue precisamente dilatar la notificación con el fin de que sus oficiales en campaña ampliaran al máximo el radio de acción de sus tropas.

Así por ejemplo, durante esos días el vicepresidente Francisco de Paula Santander anunció que el comandante Montilla no estaba obligado a suspender las hostilidades hasta tanto no le informaran oficialmente sobre el acuerdo, tiempo que sería valioso para ganar más territorio después de haber salido victorioso en la toma de la ciudad de Santa Marta, teniendo como mira la posibilidad de invadir a Maracaibo ${ }^{23}$.

El primer paso para aplicar el armisticio a nivel regional fue nombrar los comisionados que acordarían trazar una línea divisoria en las provincias que hacían parte de la región Caribe: Santa Marta, Cartagena y Riohacha ${ }^{24}$. El coronel Justo Briceño Otálora fue nombrado como comisionado del bando republicano mientras que el oficial Manuel Landa, capitán de Húsares de Fernando VII, fue designado por el general Pablo Morillo. Ambos ya tenían experiencia por cuanto habían participado en la demarcación de Maracaibo.

Con base en estos antecedentes y, en el marco del Bicentenario de la Independencia de Colombia, este artículo tiene por objeto analizar el proceso de delimitación de territorios y cese al fuego decretado por el armisticio firmado en 1820 en Trujillo, así como también ver en detalle las complicaciones que giraron en torno a su aplicación en las provincias de la región Caribe colombiana.

\footnotetext{
${ }^{22}$ AGN, Sección Colecciones, Fondo Enrique Ortega Ricaurte, Serie Legaciones y Consulados, caja 121, carpeta 1, ff. 1r-8r; "Armisticio", Correo del Orinoco, No. 91, Angostura, diciembre 30 de 1820.

${ }^{23}$ Roberto Cortázar (Comp.), Cartas y Mensajes del General Francisco de Paula Santander, Vol. II (Bogotá: Academia Colombiana de Historia, 1956), 448.

${ }^{24}$ Roberto Cortázar (Comp.), Correspondencia dirigida al General Santander, Vol. VII (Bogotá: Academia Colombiana de Historia, 1969), 409.
} 
Este trabajo se inscribe dentro del propósito por avanzar hacia una nueva mirada del periodo de Independencia pues la historiografía colombiana se ha centrado más que todo en una apología al heroísmo militar, en el desarrollo de las batallas y en las estrategias militares aplicadas. Así entonces, resulta pertinente también mirar este proceso de emancipación desde la perspectiva de la negociación y de la búsqueda de la paz que se exploraron durante estos años con la esperanza de que este tipo de análisis pueda arrojar algunas claves que a manera de antecedente sirvan para entender los procesos posteriores de reconciliación vividos a lo largo de la convulsionada vida republicana.

Esta investigación se realizó principalmente con base en fuentes primarias de información como los archivos documentales, el intercambio epistolar entre autoridades políticas y militares, los informes oficiales, las memorias, las crónicas, los diarios de campaña y los artículos de prensa de la época. Esto fue complementado con la revisión de artículos y libros alusivos a la temática objeto de estudio. Debe reconocerse por anticipado que la mayor parte de las fuentes disponibles corresponden al bando republicano, lo cual desde luego incidió en un mayor análisis y detalle de las actividades, estrategias y decisiones asumidas por ellos durante esta coyuntura de tregua.

\section{Delimitación y reacciones populares en las provincias de Santa Marta y Riohacha.}

Dentro de las recomendaciones previas a la demarcación territorial en las provincias de Santa Marta y Riohacha, el presidente Simón Bolívar advirtió al comandante Mariano Montilla que era clave mantener despejadas las comunicaciones entre el cuartel general de Trujillo, el cuartel general de Turbaco y las fuerzas que operaban en Santa Marta. A comienzos de diciembre de 1820, pocos días después de firmado el armisticio, se le hizo saber a Montilla que debía tranquilizar la provincia de Santa Marta y para ello había que sacar de allí a todos los que se mostraran desafectos con la causa libertadora y debía además adelantar acciones para aumentar su pie de fuerza ${ }^{25}$.

Los comisionados Briceño y Landa arribaron el 18 de este mes a la ciudad de Santa Marta ${ }^{26}$ y comunicaron al gobernador español de la plaza de Cartagena y al comandante Montilla el contenido de los tratados. Ese mismo día recibió una copia del acuerdo el almirante Luis Brión,

\footnotetext{
${ }^{25}$ Roberto Cortázar (Comp.), Correspondencia dirigida..., Vol. III, 280.

${ }^{26}$ BNC, Fondo Archivo Histórico Restrepo, Fondo I, Vol. 15, pieza 5, ff. 187r-188r.
} 
comandante de las fuerzas marítimas republicanas. De inmediato, dio a conocer esta noticia a todas las embarcaciones que surcaban el mar Caribe $^{27}$.

El panorama en la provincia de Santa Marta mostraba avances progresivos para las tropas republicanas. La ciudad capital había sido ocupada por estas fuerzas el 10 de noviembre. El cese de hostilidades sorprendió al coronel Juan Salvador de Narváez en la población de Valencia de Jesús en momentos en que lanzaba su ofensiva contra el distrito de Valledupar y con miras a respaldar al coronel José Sardá en la provincia de Riohacha ${ }^{28}$. Entre tanto, la ciudad de Ocaña, adscrita también a la jurisdicción de la provincia de Santa Marta, se hallaba bajo el poder de los republicanos pero vulnerable ante el incesante asedio de guerrillas realistas. Cabe aclarar que tanto el coronel Montilla como sus oficiales en terreno no asimilaron con mucha complacencia la noticia del armisticio pues habían percibido un ambiente favorable al sistema republicano y eran muy optimistas sobre los resultados de la campaña que tenía como meta final la invasión a Maracaibo ${ }^{29}$.

En el territorio de la provincia de Riohacha se advertía un mayor equilibrio de fuerzas. Su capital del mismo nombre se hallaba en total abandono después de haber sido incendiada por los irlandeses al servicio de la República. Cuando uno de los delegados llegó allí, únicamente halló tres mujeres y un esclavo, quienes informaron que los patriotas estaban concentrados con un pie de fuerza aproximado de 115 soldados en la cercana población de Camarones en donde habían buscado refugio los emigrados de Riohacha. Por su parte, las fuerzas realistas estaban bajo las órdenes del teniente coronel Miguel Gómez a cuatro leguas de distancia al noreste de Riohacha, siendo conformadas por 70 militares entre españoles e indios guajiros. El comisionado Landa comunicó a Gómez que, en virtud del armisticio, debía cesar sus hostilidades y replegar hacia Riohacha las partidas que rodeaban a Camarones ${ }^{30}$.

Previo al proceso de demarcación, Briceño se había reunido con el coronel Montilla con el fin de enterarse del estado de ambas provincias y de la ubicación de las tropas republicanas, después de lo cual recibió instrucciones precisas para que la demarcación se ajustara a lo dictaminado por

\footnotetext{
27 AGN, Sección República, Fondo Secretaría de Guerra y Marina, tomo 328, ff. 96r-97v; Roberto Cortázar, Correspondencia dirigida..., Vol. III, 431

${ }^{28}$ Mario Briceño Perozo (Comp.), Vida y papeles de Justo Briceño (Caracas: Gráficas Continente, 1970$), 131$.

${ }^{29}$ AGN, Sección República, Fondo Secretaría de Guerra y Marina, tomo 333, f. 65r; Roberto Cortázar (Comp.), Cartas y Mensajes..., Vol. III, 402; Roberto Cortázar (Comp.), Correspondencia dirigida..., Vol. III, 280.

${ }^{30}$ Pilar León Tello, El Ejército Expedicionario de Costa Firme: documentos del Conde de Torrepando conservados en el Archivo Histórico Nacional. (Madrid: Real Academia de la Historia, 1985), Vol. I, 67.
} 
el tratado pero sin que en ningún momento este proceso fuera en detrimento de la victoria y ocupación alcanzadas en estos territorios ${ }^{31}$.

El teniente coronel republicano Antonio Piñeres y el oficial español Manuel Herrera fueron designados para la exacta demarcación en terreno y para velar por el estricto cumplimiento de lo acordado. Con base en esta información recopilada, los negociadores Landa y Briceño se trenzaron en un juego de poderes en procura de defender cada uno sus intereses y medir la reacción de la contraparte.

Tras varios intentos fallidos, Landa convino reunirse con el coronel Montilla en busca de nuevas luces que abrieran camino a un pronto acuerdo. Este comisionado se mostró bastante preocupado al pensar que estas demoras podían traer consecuencias funestas que automáticamente retardarían la demarcación en la provincia de Cartagena. Briceño coincidía con estos temores y por ello hizo un llamado a su contraparte para que llegaran finalmente a un consenso pues era inmensa la responsabilidad que sentían con miras a no ver frustrados los loables propósitos planteados en el $\operatorname{armisticio~}^{32}$.

En un acto de sensatez, finalmente las partes se apartaron por un momento de sus diferencias y el 23 de diciembre firmaron el convenio de nueve puntos que en buena parte recogía la propuesta presentada por el coronel Montilla. Así entonces, se trazó una línea divisoria ente las provincias de Riohacha y Santa Marta, tomando prácticamente como referencia la división natural de estos dos marcos territoriales (Ver Mapa 1). En términos generales, el propósito de este acuerdo fue garantizar que la primera de estas áreas quedara bajo el mando español mientras que la segunda permanecería adscrita al régimen republicano.

En relación con la provincia de Riohacha, en el primer numeral se determinó que los pueblos de Camarones y Treinta, además de cualquier otro sitio que pudieran haber ocupado las huestes al servicio de la causa emancipadora, debían ser evacuados y quedarían como los demás que estaban bajo amparo español. Esto se hizo con el fin de mantener íntegro todo el territorio de esta provincia bajo un mismo mando y facilitar así la observancia de lo pactado.

\footnotetext{
${ }^{31}$ Mario Briceño Perozo (Comp.), Vida y papeles..., 101.

${ }^{32}$ Mario Briceño Perozo (Comp.), Vida y papeles..., 136.
} 
Mapa $1^{33}$. Demarcación de límites acordados entre republicanos y españoles el 23 de diciembre de 1820 en las provincias de Santa Marta y Riohacha, y el 25 de enero de 1821 en la provincia de Cartagena

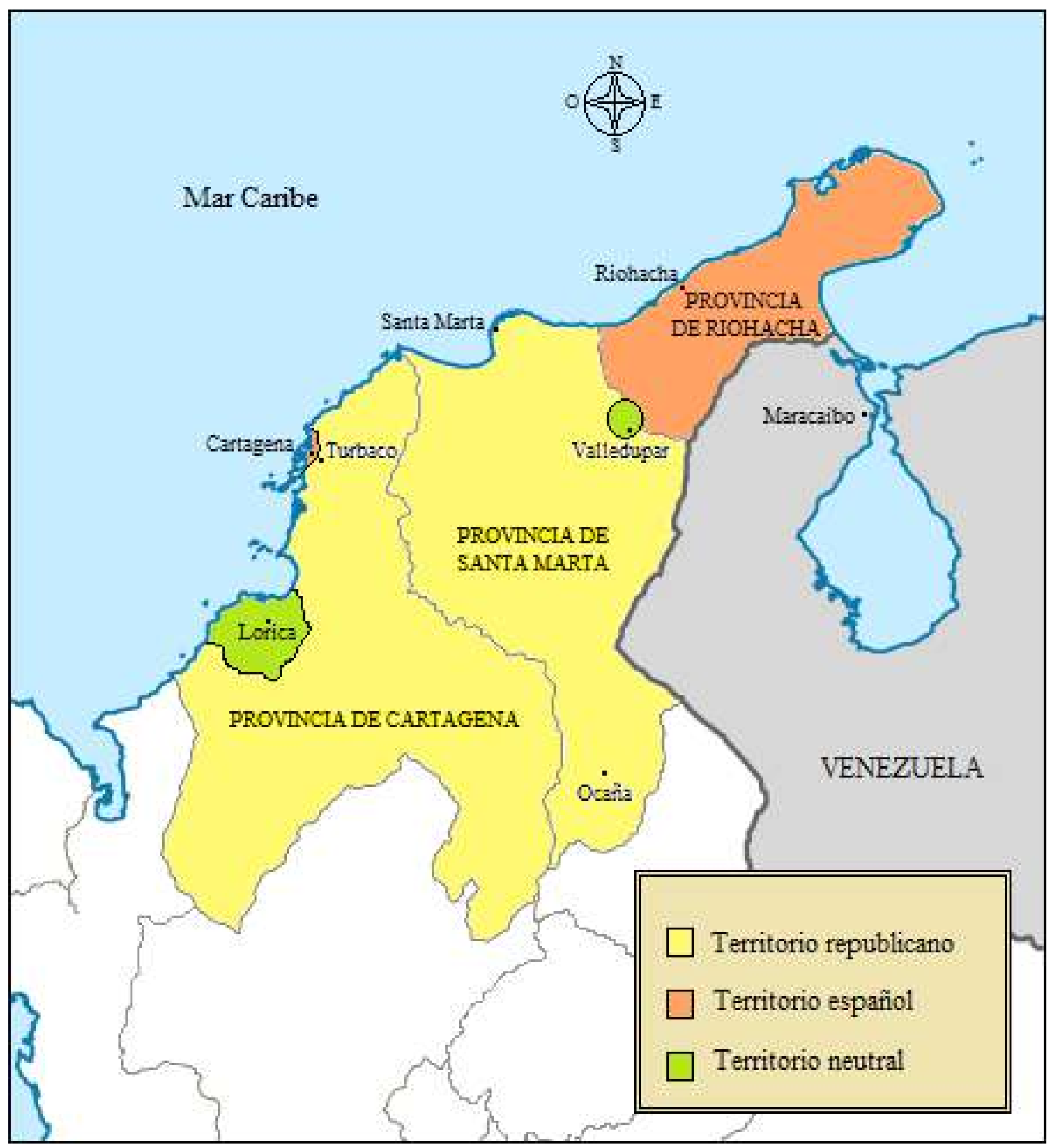

${ }^{33}$ Fuente: Mario Briceño Perozo (Comp.), Vida y papeles..., pp. 136-138; AGN, Sección República, Fondo Secretaría de Guerra y Marina, tomo 333, ff. 116v-117v. 
Las poblaciones de Barranca, Fonseca, Badillo, San Juan, Tablado, Molino, Villanueva y Urumita, con sus respectivas jurisdicciones, quedaban bajo la administración del gobierno español a pesar de haber manifestado las tres primeras su adhesión espontánea a la causa de la República. Este punto fue sin duda el que generó mayores disensiones pero a fin de cuentas los comisionados estimaron necesario ceder estas localidades a la línea de los realistas como recompensa por haber tomado el gobierno republicano la ciudad de Ocaña y su distrito que en el momento se hallaba invadida por más de 600 guerrilleros adictos a la causa del Rey, grupos estos que según el artículo $4^{\text {o }}$ del armisticio debían desalojar inmediatamente esta región ${ }^{34}$.

En relación con la línea divisoria entre las provincias de Santa Marta y Riohacha, se determinó que la ciudad de Valledupar y su distrito conformado por los poblados de La Paz, Tupes, el Tuerto, Pueblito, Jagua y Becerril, quedaran neutrales con el fin de facilitar las comunicaciones entre los dos ejércitos contendientes. Esta decisión sería notificada a las autoridades civiles de estas poblaciones y mientras tanto los comisionados consultarían con sus respectivos jefes la forma justa de garantizar la administración y gobierno local sin que ninguno de los dos bandos pudiera considerarlos enemigos ni tampoco remover autoridades, imponer contribuciones o reclutar a sus habitantes.

El resto de la provincia de Santa Marta, principalmente la parte limítrofe con los pueblos del interior, fue supeditada a la égida del gobierno colombiano ${ }^{35}$. Al aceptar Briceño este punto, tuvo presente la topografía de la zona y la expresa recomendación del comandante Montilla de mantener despejada la comunicación por Chiriguaná y Ocaña, además de la sugerencia de sostener a todo trance la libre y segura navegación por el río Magdalena, principal arteria fluvial entre el interior y la Costa Norte a través de la cual podía mantenerse activo el comercio y la provisión de hombres, armas y provisiones para las fuerzas acantonadas durante el tiempo del armisticio.

Al conocer a mediados de enero en Bogotá el contenido del acuerdo, Bolívar no vaciló en formular algunos reparos. Pensaba este máximo gobernante que había sido un craso error la entrega al gobierno español de los pueblos de la provincia de Riohacha dominados por los republicanos, pues era muy claro en uno de los artículos del armisticio que estos sitios debían permanecer aliados

\footnotetext{
${ }^{34}$ AGN, Sección República, Fondo Secretaría de Guerra y Marina, tomo 55, f. 364r; AGN, Sección República, Fondo Secretaría de Guerra y Marina, tomo 329, f. 141r.

${ }^{35}$ Mario Briceño Perozo (Comp.), Vida y papeles, 137-138.
} 
al bando al que estaban sometidos en ese momento. Por consiguiente, Camarones y cualquier otro pueblo que antes estuviese bajo el pabellón republicano debían ser reintegrados de inmediato.

Tampoco creía Bolívar conveniente haber declarado a Valledupar y demás pueblos limítrofes de la provincia de Santa Marta en calidad de neutrales pues buena parte de este territorio estaba ya evacuado de enemigos y sus habitantes habían expresado su clamor de depender del gobierno colombiano. Por eso, antes de llegar el aviso de armisticio, estos pueblos fueron considerados como parte integrante de los republicanos, adscritos a la recién liberada provincia de Santa Marta, para lo cual Montilla debía reclamarlos bajo esas condiciones ${ }^{36}$.

A pesar de los acuerdos finiquitados a escala territorial, varias reacciones populares frente a lo decidido por el par de negociadores encargados de la delimitación pusieron en vilo el armisticio y develaron serios vacíos procedimentales. El común denominador de estas expresiones espontáneas fue que se desarrollaron sin generar mayores disturbios.

La primera de las complicaciones surgió a raíz de la resistencia popular sucedida a principios de enero en El Molino, Camarones, Fonseca, Barranca y Riohacha, localidades que no querían quedar ni en calidad de neutrales ni bajo el amparo español, tal como lo habían convenido los comisionados. Se aseguró incluso que estos pueblos estaban dispuestos a constituirse de manera independiente si el gobierno republicano no los acogía. La situación llegó a tal nivel de tensión que los oficiales Herrera y Piñeres, enviados por ambas partes para intimarlos, debieron regresar a Santa Marta al ver que sus vidas estaban en inminente peligro. Días después, el comandante José Sardá logró sin mucha resistencia apoderarse de Riohacha y de las poblaciones de Barrancas y Fonseca habiendo desmontado varias defensas interpuestas por los españoles. Según el sentimiento palpado por las partidas invasoras, aquellas poblaciones intervenidas estaban complacidas con la retoma de los republicanos. Fue tan evidente el decidido apoyo percibido que en pocos días más de 300 moradores de estos sitios se incorporaron a aquellas fuerzas de ocupación ${ }^{37}$.

A estas incertidumbres se sumó otra más. En Valledupar emergieron también por estos días algunas manifestaciones que cuestionaron su estatus neutral. Al cuartel general del coronel Narváez llegaron sendas comunicaciones suscritas por la sala capitular y por seis vecinos "honrados" en las

\footnotetext{
${ }^{36}$ Roberto Cortázar (Comp.), Cartas y Mensajes..., Vol. III, 399.

${ }^{37}$ AGN, Sección Colecciones, Fondo Enrique Ortega Ricaurte, caja 80, carpeta 16, f. 27r.
} 
que exigían se les nombrara alguna autoridad competente que se encargara de contener la anarquía reinante y los continuos robos nocturnos que habían obligado a muchos de los habitantes a pernoctar en las afueras de la ciudad ${ }^{38}$.

A fin de evitar desórdenes peores, desde su cuartel general ubicado en Valencia de Jesús, Narváez comisionó el 7 de enero al alcalde de primera nominación de esta población para que viajara hasta Valledupar con el fin de restaurar el orden pero siempre actuando con suma imparcialidad. Su misión era reunir a la sala de regidores para notificarles la decisión de nombrar autoridad competente. Si no podía encontrar constituido este órgano de poder local, debía concentrar entonces a un buen número de vecinos "honrados" para que formaran un cabildo abierto que tendría como función primordial designar una autoridad que los gobernara provisionalmente. Al haber impartido estas instrucciones, aquel oficial republicano creía no estar infringiendo los términos del armisticio pues abrigaba la esperanza de que los españoles entenderían que su único propósito era garantizar la tranquilidad pública pero sin ninguna pretensión de injerencia militar que despertara inquietud o tensión entre las partes. De todos modos, quiso informar al par de comisionados negociadores para lo cual les envió a Santa Marta los pormenores de estas novedades, y con el comisionado remitido a Valledupar adjuntó sendas copias del armisticio, del tratado de regularización de la guerra y del convenio de demarcación para que se mostrara en detalle estos documentos a los pobladores y se superara así cualquier duda o escollo que pudiera surgir entre ellos.

Al conocer esta situación, el comandante Montilla confesó estar en una gran encrucijada pues, por un lado, sentía el impulso patriótico de proteger aquellos pueblos y, por el otro, era consciente del imperativo de cumplir con lo previamente pactado entre las partes ${ }^{39}$. Finalmente, impartió órdenes para que sus tropas invadieran aquellas comarcas ${ }^{40}$.

Hacia el mes de marzo se registró un nuevo episodio en momentos en que se empezaba a presagiar una inminente terminación del armisticio. Los vecinos de San Juan que todavía estaban bajo la égida española, enviaron el 6 de marzo una comunicación al coronel republicano José Sardá, gobernador y comandante militar de Riohacha, expresándole su interés de adhesión tras sentirse

\footnotetext{
${ }^{38}$ AGN, Sección República, Fondo Secretaría de Guerra y Marina, tomo 333, f. 73r.

${ }^{39}$ AGN, Sección República, Fondo Secretaría de Guerra y Marina, tomo 329, f. 217r.

${ }^{40}$ Roberto Cortázar (Comp.), Correspondencia dirigida..., Vol. VII, 436.
} 
acosados y amenazados por los "godos" del Molino y Villanueva. Con esto querían seguir el ejemplo de Riohacha, Fonseca y Barranca. Aunque reconocieron dificultades para unificar la voz popular y nombrar un representante, el grupo de 56 firmantes exigió la inmediata protección militar y se mostraron dispuestos a ofrendar sus vidas y sus bienes en favor de la causa independentista ${ }^{41}$. En respuesta a este clamor, Sardá movilizó el día 19 hasta ese punto una partida de 20 soldados del batallón Rifles bajo el mando del subteniente Juan Cuello. Este militar narró así los detalles de la buena acogida que experimentó a su entrada a aquella localidad: "[...] lo salieron a recibir en el camino con el Pabellón Nacional, música y demostraciones de regocijo, conduciéndolo entre mil aclamaciones al pueblo donde se disputaba por llevar alojados los soldados a sus casas" ${ }^{\prime 2}$. Para el comandante Montilla fue de gran resonancia esta adhesión por ser aquel pueblo de estratégica posición y por contar con varias haciendas ganaderas.

El 27 de marzo Bolívar avaló de manera definitiva estas operaciones pues estaba convencido de que había que reconocer la decidida y manifiesta opinión de los moradores de Riohacha, Valledupar y otros más pues sería una "violencia escandalosa" forzarlos contra su voluntad, todo esto teniendo en cuenta que no le estaba vedada al gobierno republicano la posibilidad de salvaguardarlos ante cualquier retaliación enemiga ni el armisticio tampoco prohibía esta posibilidad. Esta orden de protección se sustentaba además en la directriz que él mismo había impartido el 19 de enero para que se rectificara lo convenido con miras a que aquellas localidades quedasen bajo la autoridad de la República. Según su pensar, estos antecedentes podían servir de ejemplo para todos los casos semejantes que pudiesen ocurrir en el desarrollo del armisticio en la provincia de Cartagena o en las provincias del $\mathrm{Sur}^{43}$.

Para el 19 de abril, es decir pocos días antes del rompimiento anticipado del armisticio, las tropas patriotas al mando del coronel Francisco Carmona estaban a la espera de que la población de El Molino mostrara su disposición de adhesión a la causa emancipadora y, por otro lado, se dedicaron a perseguir la columna del teniente coronel español Miguel Gómez ${ }^{44}$.

${ }^{41}$ AGN, Sección Colecciones, Fondo Enrique Ortega Ricaurte, caja 80, carpeta 17, f. 77r.

${ }^{42}$ AGN, Sección República, Fondo Secretaría de Guerra y Marina, tomo 333, f. 247r.

${ }^{43}$ Roberto Cortázar (Comp.), Cartas y Mensajes..., Vol. III, 33; Roberto Cortázar (Comp.), Correspondencia dirigida, Vol. III, 306.

${ }^{44}$ Según pudo advertir el comisionado republicano para el 19 de diciembre esta columna estaba conformada por unos 60 o 70 hombres, la mitad de ellos soldados españoles y la otra mitad indios guajiros. Mario Briceño Perozo (Comp.), Vida y papeles..., 130. 


\section{La delimitación en la provincia de Cartagena y la disputa en Sabanas.}

Luego de cumplir su misión en las provincias de Santa Marta y Riohacha, los comisionados Briceño y Landa emprendieron camino hacia la colindante provincia de Cartagena, con el fin de proceder allí a la demarcación en torno a la plaza, máximo bastión militar de los españoles en la región Caribe colombiana ${ }^{45}$. No menos complicado resultó el proceso de delimitación en este marco territorial. Aunque el mismo Briceño había pronosticado que muy pronto concluiría su cometido, en realidad se tropezó con un complejo escenario que implicó muchos más esfuerzos que la simple delimitación del área circundante a la plaza. En el resto de la provincia, el espacio en donde se habían registrado mayores enfrentamientos militares era en los pueblos denominados en aquella época como los pueblos de Sabanas o de la costa de Sotavento ${ }^{46}$, es decir aquellos ubicados al suroeste de la ciudad de Cartagena, en el valle del río Sinú ${ }^{47}$.

Briceño y Landa arribaron el 26 de diciembre a Turbaco ${ }^{48}$, cuartel general del comandante Montilla y centro de operaciones de las huestes republicanas que estrechaban su cerco a cuatro leguas del puerto de Cartagena. De inmediato los oficiales que operaban en la zona fueron notificados del cese de hostilidades.

Los diálogos se desarrollaron al interior de la plaza y el 31 de diciembre el comisionado Briceño propuso la siguiente demarcación en torno a la ciudad amurallada que en buena parte se ajustaba a la existente línea de Turbaco que dividía dichas fortificaciones del territorio cubierto por el ejército republicano:

Artículo $1^{\circ}$. Ocupada la plaza de Cartagena por las armas españolas, quedan sujetas a ellas por la parte del sur el territorio comprendido desde la plaza hasta la punta del Manzanillo en la bahía, tirándose una línea por Alcibia hasta la orilla de la laguna de Tesca; por la de Este el terreno que se comprende entre el mar y la laguna de Tesca

\footnotetext{
${ }^{45}$ AGN, Sección República, Fondo Secretaría de Guerra y Marina, tomo 55, f. 364r.

${ }^{46}$ AGN, Sección Colecciones, Fondo Enrique Ortega Ricaurte, caja 80, carpeta 16, f. 21r.

${ }^{47}$ Vale recordar un antecedente en torno a esta región en el episodio que se denominó "revolución de las sabanas" ocurrido entre septiembre y noviembre de 1812, cuyo objetivo principal fue el de derrocar al recién independizado Estado de Cartagena y restablecer en estas provincias costeras el régimen español. Sobre esta temática, véase: Armando Martínez Garnica y Daniel Gutiérrez Ardila, La contrarrevolución de los pueblos de las Sabanas de Tolú y el Sinú (1812) (Bucaramanga: Universidad Industrial de Santander, 2010).

${ }^{48}$ Roberto Cortázar (Comp.), Correspondencia dirigida, Vol. III, 163.
} 
hasta la orilla izquierda del caño de la Boquilla y por la de Oeste la lengua de tierra que se extiende hasta Bocagrande, toda la isla de Tierra Bomba y toda la de Barú hasta la orilla derecha del caño del Estero. $2^{\circ}$. Lo restante de la provincia no expresado en el anterior artículo, continuará ocupado por las fuerzas de Colombia. La porción de la laguna de Tesca y la de Bahía será de ambas partes ${ }^{49}$.

Como segundo punto, Briceño propuso que el resto de la provincia continuara ocupada por las fuerzas republicanas.

Inadmisible era para Landa el primer numeral de esta propuesta tras argüir que las tropas republicanas no tenían ningún punto militar desde la Boquilla y Ternera hasta la plaza ni tampoco al interior de la bahía y, por tanto, no podía concedérseles allí territorio en detrimento de los intereses españoles. En respuesta a estas observaciones, el comisionado español pidió rectificar de este modo la demarcación con una línea “[...] empezando por la línea izquierda de la Boquilla y prolongándose por la del sur de la ciénaga de Tesca hasta Ternera y Buenavista, desde este punto tirando una recta a Pasacaballos siguiera por el camino del Estero hasta su desembocadura en el golfo de Barú, y desde este corriendo la costa hasta la batería de Cispatá" ${ }^{50}$.

Briceño aclaró que las avanzadas republicanas se habían instalado en la Boquilla, Juncalito, Arenal, Buenavista, Turbaná y Rocha, y sus tropas descubiertas habían recorrido las orillas de la laguna de Tesca y los lados del sur de la bahía al igual que el terreno intermedio desde la punta del Manzanillo por Alcibia hasta la expresada laguna, sin ser nunca molestadas por las fuerzas adversarias. Prueba de ello eran las embestidas sufridas por la escolta de la plaza al salir a esos terrenos en busca de leña. Se hizo énfasis en que el criterio que debía regir en este caso era el área a través de la cual se movían y no necesariamente la ocupación permanente.

Igual de inaceptable era para Landa el segundo punto que a fin de cuentas sería el nudo gordiano de las negociaciones en esta provincia. El comisionado español explicó que, aparte del dominio ejercido sobre la plaza, recientemente las tropas al mando del capitán de milicias José Candamo habían ocupado legítimamente los pueblos de Sabanas, dentro de los cuales se incluía a Lorica, San Antero, Lobo, San Bernardo, San Juan de las Palmas, La Purísima, San Nicolás, San

\footnotetext{
${ }^{49}$ Mario Briceño Perozo (Comp.), Vida y papeles, 141.

${ }^{50}$ Mario Briceño Perozo (Comp.), Vida y papeles, 111.
} 
Sebastián de Urabá y Palo de Aguas. El gobierno español no estaba dispuesto a renunciar a su posesión y a su derecho de protegerlos para lo cual había que trazar una línea que los incluyera “[...] desde la batería de Cispatá hasta el pueblo de San Andrés, desde éste hasta la ciénaga de La Cruz y siguiendo el caño de Lorica hasta entrar en el Sinú continuando su corriente hasta el paralelo del pueblo de San Nicolás, desde donde se tirará una recta a la ensenada de Rada"51.

Torres estaba convencido de que no había que fijarse tanto en las líneas divisorias sino que el objetivo central del armisticio era evitar el derramamiento de sangre y garantizar la tranquilidad pública y la comunicación de los pueblos. Los republicanos, por su parte, creían que este proceso de demarcación de límites no era un asunto insustancial sino prácticamente el único medio disponible y confiable para precaver desórdenes y confusiones.

Briceño siguió insistiendo en culpar a los españoles por obrar de mala fe al ocupar la región de Sabanas. Por informaciones más precisas recibidas días después, este comisionado pudo percatarse de que en realidad Candamo se había dedicado desde el 20 de diciembre a saquear e incendiar las poblaciones de Lorica, Chimá y Chinú habiendo asesinado varios individuos. Con estas nuevas y contundentes pruebas, se exigió que Candamo y su tropa regresaran a la plaza y detuvieran de inmediato sus atropellos. Movido por la confianza que debía imperar en medio de la negociación, Briceño abrigaba la esperanza de que había sido una conducta arbitraria e insubordinada de este oficial, no avalada por el gobernador Torres.

Landa se dedicó a aclarar que en ningún momento el gobierno español había obrado de mala fe. Aunque era consciente de que a nadie más se le podía imputar culpabilidad que al propio oficial Candamo, por otro lado intentó justificar sus excesos bajo el argumento de que desconocía por completo la orden de tregua puesto que la carta del 18 de diciembre en donde el gobernador le notificaba sobre este asunto había sido interceptada por tropas republicanas. Ante este impasse, Torres había enviado una segunda notificación el 27 de diciembre sobre suspensión de hostilidades pero se contempló la posibilidad de que Candamo no la hubiese recibido antes del $1^{\circ}$ de enero debido a la distancia en que estaba localizado y, por consiguiente, no se le podía endilgar responsabilidad alguna en sus acciones cometidas hasta el 30 de diciembre. Sobre los asesinatos y

${ }^{51}$ Mario Briceño Perozo (Comp.), Vida y papeles, 111-112. 
otros abusos que pudo haber cometido este oficial, el gobierno español prometió adelantar las respectivas averiguaciones.

Con miras a conjurar esta problemática, Landa manifestó su voluntad de ceder en sus pretensiones para facilitar un acuerdo. La idea consistía en que los republicanos reconocieran la neutralidad de los pueblos ocupados a cambio de que Candamo los evacuara inmediatamente y regresara a la plaza. En la mañana del 7 de enero Landa endureció su posición y concedió a Briceño un plazo perentorio de 24 para responder a esta propuesta o de lo contrario lo conminaba a abandonar la plaza pues consideraba que él era el responsable del estancamiento de las negociaciones, motivo por el cual creía conveniente la intervención de sus superiores para resolver esta situación pero siempre con el convencimiento de que había que mantener por encima de todo el cese de hostilidades y la libre comunicación entre los lugareños.

En realidad, Briceño había dilatado intencionalmente su respuesta al pensar que lo que estaba en juego no era de poca monta y por ello veía imprescindible elevar consultas previas y escuchar instrucciones del comandante Montilla, quien por esos días estaba en la villa de Soledad recuperándose de una leve enfermedad. La demora de los republicanos en emitir una respuesta recrudeció el ambiente de tensión y Briceño, ofendido por el ultimátum lanzado por Landa, debió finalmente desalojar la plaza a las nueve de la noche de ese día 7 de enero y regresar al cuartel general de Turbaco ${ }^{52}$. Le preocupaba además a este oficial el hecho de que las autoridades españolas habían ordenado a las corbetas y fragatas permanecer en estado de alerta ${ }^{53}$. Landa, entre tanto, oficializó también ante sus superiores la culminación de su papel como negociador.

El gobernador Torres no ocultó su preocupación por este distanciamiento y así lo dejó plasmado en una comunicación urgente que despachó esa misma noche al coronel republicano Ramón Ayala, comandante interino de la línea de Turbaco, haciéndole ver su disposición de proseguir con los diálogos a fin de no perturbar el desarrollo del armisticio para lo cual, al igual que su adversario, creía necesario mantener la tregua mientras todo se destrababa.

\footnotetext{
${ }^{52}$ Mario Briceño Perozo (Comp.), Vida y papeles, 104; Roberto Cortázar (Comp.), Correspondencia dirigida, Vol. III, 164.

${ }^{53}$ AGN, Sección República, Fondo Secretaría de Guerra y Marina, tomo 329, f. 144r.
} 
Retirado ya en el cuartel general de Turbaco, Briceño insistió en la buena fe de su gobierno, lo cual se podía constatar claramente en el avance del acuerdo realizado en la provincia de Riohacha en donde, pese a todos los reparos y sacrificios, habían cumplido con el compromiso de evacuar los pueblos declarados de común acuerdo como neutrales y, por eso, se instaba al adversario a declinar en sus injustas pretensiones territoriales en Sabanas. Con base en este antecedente, Briceño hizo llegar a Landa una contrapropuesta consistente en que, si el gobierno español desistía de su intención de apoderarse de la región de Sabanas, los republicanos estarían dispuestos a ceder más terreno dentro de la línea de demarcación en torno a la plaza propuesta el 31 de diciembre ${ }^{54}$.

El gobierno que defendía la plaza de Cartagena se negó a acceder a esta propuesta ante lo cual el comandante Montilla ordenó a mediados de enero movilizar desde la villa de Mompós una partida de un centenar de hombres que, junto con 210 veteranos salidos del cuartel general de Turbaco y otros efectivos más del batallón Girardot apostado en Santa Marta, debían reunirse en la región de Sabanas con el fin de tranquilizar los pueblos sublevados y evitar nuevas "felonías" del adversario. Simultáneamente, se estimó conveniente reforzar la línea divisoria pues se rumoraba que el gobernador Torres estaba maquinando un ataque mayor ${ }^{55}$.

Ante estas novedades, Bolívar insistió en que se devolvieran a la República estos pueblos de Sabanas y pidió a Montilla adoptar las medidas preventivas ante el inminente cese de hostilidades, lo cual implicaba emprender acciones con miras a apoderarse y salvaguardar los pueblos en cuestión si el gobernador seguía rehusándose a la entrega. Se debía además exigir la devolución de cuatro bongos de guerra aprehendidos por el oficial Candamo en Tolú, los cuales no debían ponerse en depósito en la plaza sino que debieron ser considerados dentro del marco de la neutralidad ${ }^{56}$.

En respuesta a estas instrucciones, el 18 de enero Montilla lanzó un ultimátum de 24 horas para evacuar Lorica y sus poblaciones circunvecinas o de lo contrario sus huestes entrarían a invadir. Torres pidió un compás de espera de tres días mientras elevaba consultas a la junta militar de la plaza, después de lo cual decidió finalmente reconocer el carácter neutral del área invadida por Candamo y además permitió que las fuerzas sutiles republicanas que, en medio del sorpresivo ataque de los españoles habían quedado atrapadas en el río Sinú, pudieran navegar hasta ubicarse

\footnotetext{
${ }^{54}$ Mario Briceño Perozo (Comp.), Vida y papeles, 128.

${ }^{55}$ Roberto Cortázar (Comp.), Correspondencia dirigida, Vol. VII, 417.

${ }^{56}$ Roberto Cortázar (Comp.), Correspondencia dirigida, Vol. III, 427.
} 
en territorio propio. Cerca de la plaza, los españoles tendrían a la bahía bajo su entero dominio y por tierra hasta una distancia de dos tiros de cañón ${ }^{57}$.

Para efectos de verificar el cumplimiento de estas intenciones reconciliatorias, se firmó un acuerdo bilateral el 25 de enero entre el coronel Luis Francisco de Rieux en representación del bando republicano y el coronel Miguel Valbuena como emisario de los españoles (Ver Mapa 1). A este par de delegados sus superiores les impartieron las siguientes instrucciones: nombrar sendos comisionados encargados de verificar los sitios invadidos por Candamo, identificar las fuerzas sutiles de ocupación y tramitar su regreso a la plaza de Cartagena e inventariar los bongos y demás activos incautados con el fin de restituirlos a sus propietarios. Había además que nombrar dos oficiales, uno por cada bando, para que reasumieran la autoridad política y militar en aquellos pueblos con el fin de implantar el orden y la justicia a nivel local. Se diseñó una nueva delimitación en torno a la plaza concediendo algunas cortas extensiones de tierra a los republicanos y con el compromiso de los comisionados de fijar señales y mojones conocidos para evitar eventuales confusiones y discrepancias ${ }^{58}$.

El sargento republicano Juan Sierra fue escogido para hacer parte de la comisión de verificación en los pueblos en cuestión. Montilla no desaprovechó esta ocasión y le encargó encarecidamente a este militar adelantar en terreno algunas misiones especiales: "Procurará informarse secretamente del verdadero origen que ha producido el desafecto de aquellos pueblos y de los principales motores de la sedición, como igualmente del número de gente (que según cálculo aproximativo) que se prestó voluntariamente a favorecer la invasión de Candamo"59. Debía además con el mayor sigilo preparar los ánimos de los habitantes de esos puntos en favor de la causa republicana.

El 30 de enero Montilla envió al Sinú fuerzas sutiles al mando del coronel José Prudencio Padilla con tropas del batallón del Alto Magdalena. Con ellas remitió un cargamento de 100 fusiles con los que pretendía aumentar la capacidad ofensiva en torno a esa zona neutral. Ese mismo día, Montilla remitió al vicepresidente Santander el convenio rubricado cinco días atrás en Cartagena.

\footnotetext{
${ }^{57}$ Pilar Moreno de Ángel, Correspondencia y documentos del General José María Córdova (Bogotá: Editorial Kelly, 1974), tomo II, 7-8.

58 AGN, Sección República, Fondo Secretaría de Guerra y Marina, tomo 333, ff. 116v-117v.

${ }^{59}$ AGN, Sección República, Fondo Secretaría de Guerra y Marina, tomo 333, f. 118v.
} 
Precisamente, el principal reparo de este alto funcionario era que ningún pueblo de esa provincia, que incluía a los de las sabanas del Sinú, debía quedar neutral ni sujeto a los españoles a excepción de la plaza hasta tanto no hubiese nueva orden expresa del Libertador. Lo anterior en vista de que el gobierno colombiano ya había sido muy generoso cediendo pueblos en las provincias de Caracas y Riohacha que estaban bajo la égida de las mesnadas republicanas ${ }^{60}$.

Aunque con este acuerdo suscrito el 25 de enero se reanudaron las relaciones amistosas y se reactivaron las conversaciones en torno al canje de prisioneros ${ }^{61}$, en los meses siguientes fueron reportados algunos choques en medio de un progresivo ambiente de tensión. Así por ejemplo, el 28 de febrero se registraron combates en las líneas limítrofes en cercanías a la población de Chimá. En estas acciones los republicanos asesinaron 7 "facciosos" y 10 más fueron tomados prisioneros, además de la incautación de 3.000 cartuchos, 16 fusiles, 1 arroba de pólvora y 2 pedreros montados. Por esos días, se enviaron hombres al pueblo de San Pelayo incendiado por los españoles y se persiguieron algunos "facciosos" en el sitio de Echacuri ${ }^{62}$.

El reciente levantamiento y los atentados causados por los "facciosos" en los pueblos circundantes a Lorica incluyendo el incendio de San Pelayo, la infructuosa reclamación hecha al comandante español y la aparente hospitalidad brindada a los "revoltosos" adeptos al Rey en la línea divisoria de Cartagena, eran factores que según Montilla habían ofendido la dignidad y buena voluntad de los republicanos y, por lo tanto, ameritaban una venganza y un escarmiento a manera de respuesta. En consecuencia, aquel alto oficial dio orden el 9 de marzo al comandante general de Sabanas "[...] para que en el caso de repetirse el menor daño, desenvaine la espada y haga un ejemplar terrible que al mismo tiempo que atemorice a los malvados, llene de confianza a los individuos que se hallan bajo el gobierno de la República"63.

El 10 de abril el gobierno español aún no había atendido los reclamos de los republicanos por los últimos incidentes y Montilla estaba listo para atacar si no recibía explicaciones

\footnotetext{
${ }^{60}$ Roberto Cortázar (Comp.), Cartas y Mensajes, Vol. III, 40, 402, 416; Roberto Cortázar (Comp.), Correspondencia dirigida, Vol. III, 458.

${ }^{61}$ José Manuel Restrepo, Historia de la Revolución de la República de Colombia (Bogotá: Editorial Besanzon, 1858), tomo III, 87.

62 AGN, Sección República, Fondo Secretaría de Guerra y Marina, tomo 333, f. 244r.

${ }^{63}$ AGN, Sección República, Fondo Secretaría de Guerra y Marina, tomo 333, f. 202r.
} 
satisfactorias $^{64}$. Diez días después, según reportó el coronel Jacinto Lara, fuerzas españolas fueron batidas en cercanías a Lorica después de haber intentado sorprender a las columnas republicanas que patrullaban en esa misma zona. Este enfrentamiento ocurrió poco antes de vencerse el término de los 40 días de previsto de finalización del armisticio y fue en respuesta a la orden impartida por el vicepresidente Santander de ocupar estos pueblos declarados neutros en el convenio del 25 de enero $^{65}$. Este ambiente de tensión se mantuvo prácticamente constante hasta la reanudación de las operaciones militares ${ }^{66}$.

\section{Las manifestaciones independentistas de Maracaibo y las fuerzas guerrilleras.}

Aparte de las desavenencias y desconfianzas que pudieron suscitarse a raíz de la fijación de las líneas divisorias en las provincias de Santa Marta, Riohacha y Cartagena, emergieron también otra serie de factores externos e internos que coadyuvaron a atizar la tensión existente entre las partes y a precipitar la culminación del cese de hostilidades.

El 28 de enero de 1821 estalló una insurrección en Maracaibo, ciudad que había quedado bajo el poder de los españoles de acuerdo a la demarcación del armisticio pactado en el occidente de Venezuela. Esto generó un profundo malestar en el gobierno español que no creía que esta sublevación fuese espontánea como lo alegaban los republicanos y como había sucedido hacía algunos meses por los lados del sur, en la ciudad de Guayaquil ${ }^{67}$. Según se adujo, días antes el general patriota Rafael Urdaneta en un acto de clara provocación había ordenado desde su cuartel de Trujillo el envío de un cuerpo de infantería y después del levantamiento popular el coronel patriota José Heras se apresuró a ocupar la ciudad ${ }^{68}$.

El comandante español Miguel de La Torre lamentó este percance que empañaba la buena armonía que había reinado en medio del armisticio pactado en territorio venezolano. Lo que planteó este alto oficial en carta oficiada el 13 de febrero era que el gobierno colombiano no debía ocupar ni brindar protección al referido pueblo hasta tanto no culminara el periodo de tregua aunque dejó

\footnotetext{
${ }^{64}$ AGN, Sección República, Fondo Secretaría de Guerra y Marina, tomo 333, f. 249r.

${ }^{65}$ Roberto Cortázar (Comp.), Cartas y Mensajes, Vol. III, 190.

${ }^{66}$ José Manuel Restrepo, Historia de la Revolución de la República, tomo III, 87.

${ }^{67}$ Roberto Ibáñez, "El Armisticio", en Historia de las Fuerzas Militares de Colombia, ed. Álvaro Valencia Tovar (Bogotá: Editorial Planeta, 1993), tomo I [El Ejército], 350.

68 José Manuel Groot, Historia eclesiástica y civil de Nueva Granada (Bogotá: Imprenta a cargo de Foción Montilla, 1869), tomo III, 106-107.
} 
abierta la posibilidad de que en este lapso se gobernaran autónomamente. Si los republicanos no acogían esta sugerencia, estarían transgrediendo la línea divisoria acordada por los comisionados, caso en el cual las tropas españolas se verían abocadas a una actitud ofensiva ${ }^{69}$.

No obstante, por el intercambio epistolar y por los informes disponibles se pudo comprobar que en realidad lo ocurrido en aquella ciudad venezolana fue una sublevación espontánea por cuanto el secretario de Guerra Pedro Briceño Méndez había proyectado atacar solo hasta después de finalizado el armisticio $^{70}$.

Muy enfático se mostró el Libertador Simón Bolívar frente a este espinoso asunto pues, si bien consideraba que el oficial Heras se había apresurado en sus acciones ${ }^{71}$, de todos modos reiteraba el justo derecho que le asistía a los republicanos de proteger a todos aquellos pueblos que abrazaran la causa de la libertad. Se adujo además que el armisticio no incluyó ninguna cláusula que coartara este tipo de amparo. A pesar de todo, Bolívar expresó su disposición de entrevistarse con La Torre para superar directamente este impasse o como segunda alternativa propuso nombrar árbitros $^{72}$.

A mediados de febrero, Bolívar advirtió al comandante Montilla, quien había sido por esos días ratificado como comandante en jefe de todo el ejército republicano que actuaba en la Costa Norte, para que estuviese alerta e implementara las medidas pertinentes para reabrir las hostilidades ante la alta probabilidad de que se suspendiesen los efectos del armisticio aunque por otro lado también lo instó para que estuviera atento a brindar todas las explicaciones necesarias frente al reclamo de los españoles. En respuesta a estas instrucciones, Montilla ordenó reforzar "activa y discretamente" la vigilancia sobre la línea divisoria de Turbaco y mantener además contacto con los espías al interior de la plaza a fin de que pudiesen avisar anticipadamente cualquier orden de ataque $^{73}$. Asimismo, se impartieron instrucciones a otros oficiales de la Costa para que realizaran algunos ajustes en sus batallones y reclutaran más hombres con el objeto de tener un cuerpo de más

\footnotetext{
69 “Armisticio”, Gazeta de la ciudad de Bogotá, No. 87, Bogotá, marzo 25 de 1821, 269.

${ }^{70}$ Roberto Cortázar (Comp.), Correspondencia dirigida, Vol. VII, 436, 444.

${ }^{71}$ AGN, Sección República, Fondo Secretaría de Guerra y Marina, tomo 329, f. 434r.

72 Archivo Santander (Bogotá: Águila Negra Editorial, 1916), tomo VI, 85; Antonio Rodríguez Villa, El teniente general don Pablo Morillo. Primer Conde de Cartagena, Marqués de la Fuerte (1778-1837) (Madrid: Tipografía de Fortanet, 1910), tomo IV, 234-235; Simón B. O’Leary, Memorias del General, tomo XVIII, 64.

${ }^{73}$ AGN, Sección Colecciones, Fondo Enrique Ortega Ricaurte, caja 80, carpeta 16, f. 63r.
} 
1.000 hombres dispuestos a salvaguardar la voluntad emancipadora de Maracaibo ${ }^{74}$, ciudad valorada geográficamente estratégica para conservar las comunicaciones y el flujo de tropa con Venezuela. Para el $1^{\circ}$ abril, habiendo ya certeza sobre la fecha del rompimiento de la tregua para el día 28 de este mes, Montilla recibió órdenes del secretario de Guerra para proteger a toda costa a Maracaibo, lo cual implicaba neutralizar las fuerzas realistas existentes en Riohacha que podían amenazar aquella ciudad ${ }^{75}$.

El otro tema de álgida discusión fue en torno al accionar de las fuerzas guerrilleras. Estos grupos sirvieron como complemento de los ejércitos regulares dentro de sus estrategias militares. Sin lugar a dudas, tales operaciones de guerra irregular le imprimieron un ingrediente más de caos e inestabilidad a la lucha independentista.

En la región Caribe operaron algunos grupos guerrilleros, la mayoría de ellos levantados en contra del proyecto revolucionario criollo. Actuaron más que todo en las provincias de Santa Marta y Riohacha $^{76}$, siendo los de mayor alcance y belicosidad el grupo conocido como los Colorados. Estos combatientes estaban integrados por negros, mulatos, mestizos y algunos desertores de las filas patriotas y, desde 1818, asolaron buena parte del área circundante a la ciudad de Ocaña ${ }^{77}$. Ya en noviembre de 1820, en momentos en que se negociaban en Trujillo los términos del armisticio, se había comprobado la capacidad de fuerza de estas guerrillas cuando lograron asediar esta ciudad ante lo cual fue necesario que el general Bolívar enviara al coronel Manuel Manrique a recuperar el área invadida ${ }^{78}$.

En el artículo $4^{\circ}$ del armisticio se concertó que las guerrillas existentes debían disolverse inmediatamente. Si eran civiles debían desarmarse y si eran militares la instrucción era que regresaran a sus batallones. Vale recordar que solo con la firma del tratado de regularización se les reconoció a estos combatientes los mismos derechos que a los soldados regulares. De acuerdo con este precedente normativo, en el numeral $7^{\circ}$ del acuerdo de delimitación de las provincias de Santa Marta y Riohacha firmado el 23 de diciembre por los comisionados de ambas partes, se decidió

\footnotetext{
${ }^{74}$ Simón B. O`Leary, Memorias del General, tomo XVIII, 60.

${ }^{75}$ Simón B. O'Leary, Memorias del General, tomo XVIII, 165.

${ }^{76}$ Eduardo Pérez O., La guerra irregular en la Independencia de la Nueva Granada y Venezuela 1810-1830 (Tunja: UPTC, 1982), 207-208.

77 José Manuel Restrepo, Diario político y militar (Bogotá: Imprenta Nacional, 1954), tomo I, 95, 128; Lúmar Hernando Quintero Serpa, Los Colorados. Los guerrilleros del Rey (Bucaramanga: Sic Editorial, 2009 ), 24.

${ }^{78}$ AGN, Sección República, Fondo Secretaría de Guerra y Marina, tomo 325, f. 310r.
} 
desarmar y disolver las guerrillas existentes estando el comandante de la división republicana autorizado para recoger las armas y municiones ${ }^{79}$.

Aquellas que operaban en cercanías a la recién liberada ciudad de Santa Marta se habían adherido a la causa de la Independencia sin disparar un solo tiro. Los únicos que se mantenían en pie de lucha eran los Colorados, con una fuerza estimada de 600 hombres $^{80}$, cuyos jefes habían recibido el ofrecimiento de protección por parte del comandante republicano Mariano Montilla con el compromiso adicional de garantizarles sus grados militares. Pensaba este alto oficial que ningún efecto favorable resultaría de obligar súbitamente a estos soldados irregulares a abandonar el territorio después de notificárseles el armisticio. Siendo costumbre de ellos vivir refugiados en los montes, lo más efectivo sería seducir o capturar a algunos de sus cabecillas y así el resto contemplaría la posibilidad de retornar a la vida civil ${ }^{81}$.

A finales de diciembre estos guerrilleros realistas abandonaron la ciudad de Ocaña que habían logrado ocupar durante varios días ${ }^{82}$. El 20 de enero el coronel Miguel Figueredo, quien estaba al mando de una tropa de 500 soldados que defendían esta zona, continuaban persiguiendo estas partidas irregulares que habían huido a la población de Teorama. Figueredo y sus hombres decidieron suspender el ataque pero los "facciosos", a pesar de estar notificados, quisieron hacer caso omiso y optaron por traspasar territorio que ya había sido liberado por los patriotas. Aunque aquel oficial republicano tenía la intención de atacarlos, pensaba que esto podría poner en peligro el acuerdo aunque se tenía alguna información de que aquellas fuerzas enemigas habían empezado a retirarse a Maracaibo. Los dirigentes guerrilleros desconfiaban de la notificación del armisticio y solicitaron al bando adversario un plazo de 20 días mientras confirmaban la noticia con sus superiores $^{83}$.

Previa consulta a sus superiores, Montilla juzgó pertinente a mediados de febrero elevar un reclamo ante el gobierno español ante el incesante accionar de estas guerrillas. Para ello, el coronel Figueredo entró en comunicación con el jefe de estos grupos con la instrucción de que se

\footnotetext{
${ }^{79}$ Mario Briceño Perozo (Comp.), Vida y papeles..., 137-138.

${ }^{80}$ Roberto Cortázar (Comp.), Correspondencia dirigida, Vol. VII, 407.

${ }^{81}$ AGN, Sección República, Fondo Secretaría de Guerra y Marina, tomo 333, ff. 43r-46v.

${ }^{82}$ Roberto Cortázar (Comp.), Cartas y Mensajes..., Vol. III, 395.

${ }^{83}$ AGN, Sección República, Fondo Secretaría de Guerra y Marina, tomo 329, f. 185r.
} 
desarmaran o se retiraran entregando el territorio que ocupaban, todo esto en reverencia a lo convenido en el armisticio y a lo pactado entre los comisionados de ambos gobiernos. Se les prometió plenas garantías, permitiéndoles regresar a sus casas o salir de la provincia sin ningún peligro de retaliación. Un buen número de guerrilleros se acogieron a estos ofrecimientos tras ser conscientes de que se hallaban rodeados de fuerzas republicanas y sin posibilidades de auxilios del lado realista ${ }^{84}$. Sin embargo, no cesaron las escaramuzas por parte de algunas partidas que aun insistían en mantener su actitud ofensiva incluso hasta después de roto el armisticio.

\section{Rompimiento del tratado y reanudación de las operaciones.}

Previendo quizás lo vulnerable que era el armisticio, los líderes de ambos bandos fueron muy enfáticos en prevenir a sus subordinados y a sus tropas en terreno para que estuviesen siempre preparados para el momento en que se reanudaran las hostilidades. No había transcurrido aún una semana de haberse suscrito este tratado, cuando el Libertador Simón Bolívar estaba pensando en la necesidad de tener listos 12.000 hombres para cuando volviesen a renovarse las operaciones militares, para lo cual impartió instrucciones al vicepresidente Santander a fin de que se encargara de una tercera parte de este pie de fuerza como cuota del departamento de Cundinamarca ${ }^{85}$.

Tan pronto fue notificado Santander de la firma del armisticio dio orden también de aumentar los depósitos, redoblar las horas instrucción y tenerlos preparados por todos los medios para decidir de un solo golpe la suerte de Colombia por si se reanudaban las hostilidades ${ }^{86}$.

Lo cierto es que los continuos incidentes acaecidos y el movimiento insurreccional de Maracaibo hicieron creer a ambas partes en conflicto que pronto sería roto el acuerdo. Así lo había vaticinado a finales de febrero el vicepresidente Santander quien percibió en algunos sectores cierta complacencia en relación con la eventualidad de una ruptura anticipada ${ }^{87}$.

\footnotetext{
${ }^{84}$ Roberto Cortázar (Comp.), Correspondencia dirigida, Vol. III, 296; O’Leary, Simón B. Memorias del General, tomo XVIII, 63.

${ }^{85}$ Roberto Cortázar (Comp.), Correspondencia dirigida, Vol. III, p 279.

${ }^{86}$ Luis Horacio López Domínguez (Comp.), Administraciones de Santander 1820-1825 (Bogotá: Biblioteca de la Presidencia de la República, 1990, tomo I, 52.

${ }^{87}$ Roberto Cortázar (Comp.), Cartas y Mensajes, Vol. III, 44, 412; Cartas Santander-Bolívar (Bogotá: Biblioteca de la Presidencia de la República, 1988), tomo III, 102.
} 
La incertidumbre se sentía también en relación con la fecha exacta en que debían reanudarse los combates. Por esos días, al comandante Montilla lo asaltaba la duda de si después del 26 de mayo, fecha en la que se vencía el armisticio, debía prevenir al gobernador español de la plaza de Cartagena sobre los 40 días antes de aviso que establecía el acuerdo o si había que guardar silencio y simplemente atacar. Preguntaba además si había que lanzar ya la ofensiva sobre Urumita, Villanueva, Molino, San Juan y demás poblaciones que estaban bajo dominio español ${ }^{88}$. En esos momentos, Montilla alistaba el apoyo a Maracaibo con el envío de tropas, armas y provisiones al tiempo que aseguró haber reforzado los cuerpos que operaban bajo su mando: los batallones Antioquia, Girardot, Alto y Bajo Magdalena y Rifles de la Guardia.

Finalmente, el 10 de marzo desde su cuartel general en Trujillo el presidente Simón Bolívar comunicó al general en jefe español Pablo Morillo que se veía forzado a romper el armisticio por la falta de recursos para sostener el ejército y por las reducidas esperanzas de entablar las negociaciones de paz $^{89}$ pues no se había conseguido que los enviados españoles, el brigadier de la Armada José Sartorio y el capitán de fragata Francisco Espelius, se sentaran a dialogar con los delegados republicanos José Rafael Revenga y José Tiburcio Echeverría.

En razón a estos impasses, Bolívar informó que los 40 días convenidos en el artículo 12 del armisticio empezarían a contar desde el momento mismo en que fuera recibida esta notificación, que se estimaba fuera en un plazo no mayor de 10 días, es decir, a más tardar el 20 de marzo. Así entonces, se calculaba que el $1^{\circ}$ de mayo podía quebrantarse definitivamente la tregua ${ }^{90}$.

Tras la renuncia de Morillo, asumió como comandante en jefe español el general Miguel de La Torre, quien no dudó en culpar al general Bolívar por las reiteradas infracciones y la falta de voluntad de paz. Calificó de extraña e intempestiva la decisión de aquel máximo oficial patriota al plantear como pretexto el hecho de que el armisticio le estaba causando perjuicios a su ejército ${ }^{91}$.

En consecuencia con estas novedades, el secretario de Guerra Pedro Briceño Méndez pidió al vicepresidente Santander prevenir a los jefes militares dependientes de su jurisdicción para que

\footnotetext{
${ }^{88}$ Roberto Cortázar (Comp.), Correspondencia dirigida, Vol. VII, 456.

${ }^{89}$ Roberto Cortázar (Comp.), Cartas y Mensajes, Vol. III, 431.

${ }^{90}$ Roberto Cortázar (Comp.), Cartas y Mensajes, Vol. III, 93-94, 425.

${ }^{91}$ AGN, Sección República, Fondo Secretaría de Guerra y Marina, tomo 327, ff. 787r-788v; "Armisticio”, Correo del Orinoco, No. 101, Angostura, abril 14 de 1821, 1.
} 
estuvieran alertas en esta coyuntura. El 29 de marzo, Santander ordenó al comandante Montilla informar a los jefes adversarios que el 30 de abril terminaría el armisticio $^{92} \mathrm{y}$, de manera especial, recomendó tener mucho cuidado en respetar la fecha definitiva y estar muy prevenidos para defenderse por si ellos incurrían en "felonía" al intentar asestar un golpe de sorpresa o anticiparse a romper el armisticio.

Santander le aclaró a Montilla haciéndole ver que no podía incursionar sobre aquellos pueblos que aún se mantenía obedientes al gobierno español pues solo debía intervenirlos si había alguna manifestación espontánea a favor de las banderas republicanas ${ }^{93}$. Sobre los pueblos de Sabanas, aquel comandante de la Costa estaba autorizado para utilizar la fuerza en los casos en que fuera necesario y castigar a los revoltosos ${ }^{94}$.

El 10 se abril Montilla informó haber enviado un edecán para que comunicara la decisión al gobernador español asentado en la ciudad de Cartagena ${ }^{95}$, quien seguía empecinado en rechazar las quejas alusivas a los pueblos neutros de Lorica y al incidente de los bongos pues, según adujo, ninguna resolución habían emitido sus mandos superiores y nada nuevo se había acordado a lo ya estipulado por los comisionados el 25 de enero y, por tanto, cualquier ocupación que intentaran los patriotas sería considerada como una inexcusable infracción.

Nuevas circunstancias terminaron exacerbando aún más los ánimos pues Montilla aseguraba que el gobernador había ordenado la salida de 200 fusiles de la plaza para auxiliar los pueblos neutros de Sabanas, todo esto sin que aún se decretara oficialmente el fin del armisticio. Este señalamiento fue enfáticamente refutado por Torres quien reafirmó haber realizado ese envío después de llegado el correo notificatorio de La Torre y justificaba su decisión en el derecho a defender aquellos pueblos ante la intención de los republicanos de ocuparlos ${ }^{96}$.

En la tarde del 15 de abril Torres informó a la guarnición de su plaza sobre el fin del armisticio. Aunque se hizo un llamado a seguir aplicando el tratado de regularización de la guerra, al mismo tiempo se arengó a la tropa para que con valor y disciplina lograran vencer al enemigo ${ }^{97}$.

\footnotetext{
92 AGN, Sección República, Fondo Secretaría de Guerra y Marina, tomo 333, f. 251r.

${ }^{93}$ Roberto Cortázar (Comp.), Cartas y Mensajes, Vol. III, 434.

${ }^{94}$ Roberto Cortázar (Comp.), Cartas y Mensajes, Vol. III, 435.

95 AGN, Sección República, Fondo Secretaría de Guerra y Marina, tomo 333, ff. 268r-269v.

96 AGN, Sección República, Fondo Secretaría de Guerra y Marina, tomo 333, ff. 268r-269v.

${ }^{97}$ Órdenes militares, 47.
} 
Al cabo de dos días, lanzó una enérgica proclama culpando a sus rivales del fracaso del armisticio por los sucesos de Maracaibo y por no haber correspondido a los "magnánimos y generosos" ofrecimientos del Rey ${ }^{98}$.

Al mismo tiempo, arengó a sus huestes para que reanudaran con honor y heroísmo la lucha que ellos mismos reconocían como desigual en esa crucial coyuntura pues eran conscientes de la superioridad de las huestes enemigas. Como una voz de estímulo, se informó sobre el nombramiento de don Juan de la Cruz Murgeón como capitán general de la Nueva Granada y se anunció la llegada de recursos y de varios contingentes desde la ciudad de La Habana para fortalecer la guarnición de la plaza. En el discurso a los moradores de la plaza, se reiteró el intento conciliador de los españoles y se criticó la actitud de Bolívar de aprovecharse de esta buena fe para maquinar sus "malévolos" planes".

Al llegar a través de espías a manos de Montilla estas vehementes proclamas, no vaciló en protestar por el tono guerrerista e insultante allí plasmado en donde era claro que ya no se trataba a Colombia como una República sino como la Nueva Granada, denominación de clara remembranza colonial. A sus ciudadanos ahora se les calificaba de "disidentes" y a Bolívar ya no se le consideraba como Presidente sino simplemente como un “caudillo". Torres no vaciló en seguir enfilando sus ataques verbales al señalar que entre los republicanos cundía el desorden y que en sus ejércitos solo se veían aventureros militares de varias naciones. Para este comandante, el único gobierno legítimo a nivel internacional era el de España.

Tras el cruce de cartas entre estos dos comandantes en terreno, se determinó que la ofensiva militar a los pueblos de Sabanas por parte de los republicanos y el envío de los fusiles ordenado por los españoles, eran motivos más que suficientes para interrumpir toda comunicación o diálogo entre las partes por mar y por tierra, al tiempo que al interior de la plaza se implementaron los dispositivos de alarma y defensa militar. En consecuencia, se decretó el 19 de abril el "completo estado de guerra" en toda la extensión de la línea ${ }^{100}$.

\footnotetext{
98 Órdenes militares, 47-48; Gazeta de la ciudad de Bogotá, No. 100, junio 24 de 1821, 324.

${ }^{99}$ AGN, Sección República, Fondo Secretaría de Guerra y Marina, tomo 333, f. 275r-v.

100 AGN, Sección República, Fondo Secretaría de Guerra y Marina, tomo 333, ff. 268r-269v; Roberto Cortázar (Comp.), Correspondencia dirigida, Vol. III, 470.
} 
Al día siguiente, el gobernador español ordenó invadir los pueblos cercanos a Lorica. A pesar de ser tomadas por sorpresa, las fuerzas republicanas lograron valerosamente repeler el ataque de los 500 soldados que hacían parte del Regimiento de León, combate en el que resultó herido el comandante Candamo mientras que muchos de sus hombres huyeron despavoridamente debiendo todos retirarse a la plaza de Cartagena ${ }^{101}$. Entre tanto, las huestes patriotas sufrieron 3 bajas y 15 heridos $^{102}$.

Al conocerse el rompimiento del acuerdo, se escucharon voces al interior del bando republicano que incitaban de nuevo al espíritu patriótico para sellar con éxito el proyecto independentista emprendido años atrás. Para ellos era muy claro que la responsabilidad de la culminación anticipada del armisticio era exclusivamente de los españoles. Desde su cuartel general de Barinas, el presidente Simón Bolívar elevó el 25 de abril dos proclamas, una de ellas dirigida a los pobladores y militares españoles, reiterándoles el ánimo conciliador de los republicanos y la poca acogida a los ofrecimientos de paz planteados por el comisionado enviado a Londres. La otra proclama la dedicó a sus soldados a quienes envió una voz de aliento y de optimismo pues creía que estaba muy cerca la victoria definitiva ${ }^{103}$.

El 28 de abril el coronel Juan Salvador de Narváez, gobernador y comandante militar de Mompós, dio a conocer este par de proclamas y, además de esto, dictó un bando mediante el cual adoptó una serie de medidas para posicionar a su territorio en estado de defensa. El $1^{\circ}$ de mayo era la fecha límite en la cual debían salir todos los vasallos del Rey de España y los que se mostraran indiferentes al régimen republicano, siendo los omisos considerados "enemigos públicos". Los visitantes debían traer pasaporte y se convocó a todos los ciudadanos para que respondieran oportunamente a los llamados de reclutamiento o, de lo contrario, serían tildados de traidores a la Patria. El gobernador acordó con el vicario eclesiástico programar nueve días de rogativas y preces en favor del triunfo de la causa republicana ${ }^{104}$.

\footnotetext{
101 Justo Cuño Bonito. Crimen y perdón. El juicio en La Habana al gobernador Gabriel de Torres y Velasco por la entrega de la Plaza de Cartagena (1824-1827). Estudios Ibero-Americanos, 36-2, (2010), 294.

102 "Provincia de Cartagena", Gazeta de la ciudad de Bogotá, No. 97, Bogotá, junio 3 de 1821, 309; Roberto Cortázar (Comp.), Cartas y Mensajes, Vol. III, 190.

${ }^{103}$ Vicente Lecuna (Comp.), Proclamas y discursos del Libertador (Caracas: Lit. y Tip. del Comercio, 1939), 258260 .

${ }^{104}$ AGN, Sección República, Fondo Secretaría de Guerra y Marina, tomo 6, ff. 173r-176v.
} 
Ante el rompimiento del acuerdo, ambos bandos se dedicaron a fortalecer su pie de fuerza y a escalar sus operaciones. El 4 de mayo, bajo el mando del general José Padilla, a través del canal del Dique lograron entrar las fuerzas sutiles patriotas a la bahía de Cartagena, con un total de 43 buques de guerra a los cuales se sumaron ocho más provenientes de Mompós, flotilla que se había fortalecido en tiempos del armisticio. Esta escuadra se ubicó en frente de la plaza ${ }^{105}$. En medio de este ambiente de zozobra, el 30 de mayo se celebró al interior de la sitiada ciudad amurallada el día del Rey Fernando VII con triple salva de artillería y brindis con reducidas cantidades de vino debido a la estrechez económica. Una celebración muy modesta en contraste con las pomposas y ostentosas fiestas monárquicas ocurridas en tiempos coloniales ${ }^{106}$. A fin de cuentas, sería una de las últimas celebraciones monárquicas en esta región costera.

Según los informes oficiales, a 20 de mayo las fuerzas republicanas que defendían la región Caribe llegaban a 5.227 hombres ${ }^{107}$. Tras varios esfuerzos y combates intensos, a finales de este mes las tropas al mando del coronel Francisco Carmona en cooperación con las fuerzas guiadas por el gobernador de Riohacha, coronel Carlos Sardá, lograron el control total sobre los pueblos de Valledupar, Molino, Badillo, Urumita y Villanueva, para lo cual se requirieron acciones combinadas no solo para abatir a los militares realistas sino también a la resistencia de "facciosos" aliados a la causa de España. Para el 10 de julio ya había sido doblegada la columna del teniente coronel Miguel Gómez en Riohacha y a los pocos días este oficial y otros cabecillas se presentaron en el paraje Rincón expresando su voluntad de adherirse al gobierno republicano ${ }^{108}$. Al cabo de dos semanas, el gobernador Sardá informó que todas las parcialidades de indios guajiros estaban adheridas al gobierno republicano, con el pleno ánimo de mantener la paz. Con esto, quedaba limpia toda su provincia de "facciosos" y enemigos españoles ${ }^{109}$.

En cuanto a la conflictiva región de Sabanas, por estos días el coronel Figueredo y las tropas del Alto Magdalena reportaron haberla pacificado en su totalidad tras ser disueltos los grupos guerrilleros que actuaban conjuntamente con la columna del oficial Candamo, así como también

105 Archivo Santander, Vol. VI, 166; Eduardo Lemaitre, Historia General de Cartagena (Bogotá: Banco de la República, 1983), tomo III, 217.

106 Órdenes militares, 56.

${ }^{107}$ Pilar Moreno de Ángel, Correspondencia y documentos, tomo II, 13-14.

108 AGN, Sección República, Fondo Secretaría de Guerra y Marina, tomo 333, ff. 609r, 660r, 851r.

${ }^{109}$ AGN, Sección República, Fondo Secretaría de Guerra y Marina, tomo 333, f. 726r. 
algunos lugareños descontentos que simpatizaban con la causa del Rey quienes se habían presentado y entregado las armas luego de sufrir una derrota en el sitio de Molón ${ }^{110}$. No obstante, al parecer las escaramuzas y retaliaciones siguieron activas en esta región pues en agosto una columna organizada por el coronel Narváez debió intervenir para derrotar a algunos "facciosos” en Momil, Chimá y Ciénaga ${ }^{111}$. En relación con las guerrillas de Ocaña, Montilla propuso un acercamiento que resultó infructuoso pues volvieron a reactivarse aunque a finales de año fueron $\operatorname{amnistiadas}^{112}$.

Tras el rompimiento del armisticio, también se intensificaron las acciones dirigidas a proteger a Maracaibo. Por orden de Bolívar, el 23 de mayo salieron de Santa Marta un total de 1.000 hombres con dirección hacia esta ciudad que hacía poco había declarado su independencia ${ }^{113}$. El 24 de junio el coronel Padilla, quien estaba al mando de las fuerzas sutiles, impuso su dominio militar en los castillos de San Fernando y San José de Bocachica, suceso conocido como el combate del muelle del Arsenal o "noche de San Juan", resultado de lo cual fue la captura de 11 buques con armas y municiones ${ }^{114}$. Este fue un avance estratégico para las banderas republicanas, toda vez que se logró dominar la entrada a la bahía de Cartagena y se cortó el suministro de víveres y armas provenientes de Cuba y Puerto Rico ${ }^{115}$. Este antecedente, junto con la progresiva agonía vivida al interior de la plaza, hicieron propicias las condiciones para su rendición definitiva ocurrida el 10 de octubre.

\section{Consideraciones finales.}

En términos reales, el cese de hostilidades en las provincias de Riohacha, Santa Marta y Cartagena solo duró un lapso aproximado de cuatro meses y no seis como se había pactado en un comienzo. Este anticipado rompimiento de la tregua reflejó de alguna forma la problemática allí vivida.

\footnotetext{
${ }^{110}$ AGN, Sección República, Fondo Secretaría de Guerra y Marina, tomo 333, f. 621v.

${ }^{111}$ Manuel Ezequiel Corrales, Documentos para la historia, tomo II, 471-472.

${ }^{112}$ Roberto Cortázar (Comp.), Cartas y Mensajes, Vol. III, 109, 209; O’Leary, Simón B. Memorias del General, tomo XVIII, 547-548.

113 AGN, Sección República, Fondo Secretaría de Guerra y Marina, tomo 333, f. 283r.

114 Adelaida Sourdís Nájera, "Ruptura del Estado", 183.

115 Simón B. O’Leary, Memorias del General, tomo XVIII, 461.
} 
De hecho, las autoridades de uno y otro bando fueron enfáticas en advertir a los oficiales en campaña que debían estar en máxima alerta por si en algún momento se reanudaban las operaciones. Es decir, en el ambiente de tensión estaba latente la idea de que en cualquier momento podía romperse el acuerdo. En no pocos casos, los máximos dirigentes debieron aplacar los ánimos de los comandantes en terreno exaltados por los incidentes ocurridos de manera reiterada. Ambos bandos aprovecharon cualquier ocasión para adelantar labores de espionaje o para procurar de manera discreta ganar adeptos a sus causas. Este conjunto de factores da cuenta de la fragilidad de este acuerdo de tregua, un nivel de tensión y beligerancia que en nada contribuyó a aclimatar los diálogos que se pretendían establecer.

En estos meses de armisticio quedaron además en evidencia ciertas dificultades en la coordinación de acciones entre las diferentes escalas del poder político y militar, desde las directrices impartidas por el secretario de Guerra y el presidente Simón Bolívar que tenía su cuartel en la frontera con Venezuela, el vicepresidente Santander que despachaba desde la ciudad de Bogotá como jefe máximo de todas las operaciones en el departamento de Cundinamarca, hasta los comandantes en jefe y oficiales subalternos ubicados en la región costera. Sin duda, fue en este territorio mucho más complicada la comunicación que en el occidente de Venezuela en donde las decisiones y consultas se realizaron de manera más diligente debido a la cercanía entre los máximos dirigentes republicanos y sus oficiales en terreno, así como también la facilidad de interlocución con los líderes del bando opuesto.

Por otro lado, no dejaron de suscitarse serias incongruencias entre los asuntos acordados en el convenio general suscrito en Trujillo y lo negociado por los comisionados a escala provincial, como fue el caso de los pueblos declarados neutrales en la provincia de Cartagena. Continuas fueron las consultas y dudas debido a los vacíos que dejaba la reglamentación marco del armisticio. Todo esto desembocó en el hecho de que se presentaran en la práctica muchas demoras, tanto en la notificación en cada uno de los territorios como en el proceso de rectificación de límites.

Esos intersticios en la normativa pactada en Trujillo dieron lugar a reinterpretaciones por cada uno de los dos bandos en procura de ganar más terreno en el proceso de demarcación de límites en donde, aparte de la ocupación militar como condición básica para la repartición de territorios, se arguyeron premeditadamente otros criterios como el de la presencia esporádica de 
tropas o el alcance de la artillería. Este conjunto de dificultades permite entender la constante conflictividad que se vivió en estas provincias costeras prácticamente durante todo el transcurso de la tregua, ante lo cual fue necesario en algunos casos recurrir a los comandantes jefes ante el estancamiento de las negociaciones que adelantaban los comisionados Briceño y Landa.

La normativa del armisticio tampoco previó los vacíos de poder suscitados en las poblaciones neutrales del distrito de Valledupar, lo cual generó problemas de orden público y abrió camino para una curiosa fórmula de gobierno bipartito. La problemática observada en torno a las expresiones espontáneas de algunas comunidades de Sabanas y de la provincia de Riohacha devela en cierto modo la persistencia de una fuerte beligerancia social y conflictos regionales tras más de una década de conflicto político y militar en la lucha por la independencia.

Pese al ambiente de incertidumbre y tensión, vale destacar el hecho de que las medidas humanitarias siguieron aplicándose hasta finalizar la guerra y de alguna manera significaron un alivio para el desenfrenado conflicto militar que se venía desarrollando. Aún con todas las fricciones e incidentes, en el periodo de tregua se adelantaron contactos para concretar el canje de prisioneros y por primera vez se alcanzó a manejar un lenguaje conciliatorio y respetuoso entre uno u otro bando, aunque tras la reanudación de las operaciones militares automáticamente volvieron a exacerbarse los ánimos con expresiones desdeñosas, despreciativas y ofensivas hacia el adversario.

Al momento de hacer un balance, se puede afirmar en términos comparativos que en los últimos días de la fase de la tregua los españoles estaban en una situación mucho más crítica debido al agotamiento de recursos al interior de la plaza de Cartagena y porque prácticamente se fueron desvaneciendo las posibilidades de ayuda externa tanto de la península ibérica como de los enclaves americanos que aún permanecían bajo dominio español.

Entre tanto, los efectos del armisticio no fueron tan negativos para el bando republicano pues de alguna manera permitieron el incremento del nivel de favorabilidad de la opinión pública en torno a la causa patriota. Asimismo, se observó un reforzamiento de su ejército que finalmente estrechó el cerco sobre la ciudad amurallada de Cartagena. Al mes de haber sido ocupada esta importante plaza, otras dos victorias consolidaron el dominio republicano en la Costa Caribe, la de Puerto Cabello y Panamá. 
Sin embargo, vale reconocer también que no todos estaban igual de convencidos sobre la conveniencia y favorabilidad de este cese temporal de hostilidades. El coronel José María Córdova, uno de los oficiales que había estado presente durante la fase previa y el desarrollo mismo del armisticio, creía que desde mucho antes de esta tregua las fuerzas republicanas contaban con la suficiente capacidad militar para vencer al enemigo ${ }^{116}$.

El acuerdo de paz, que era el propósito nodal del armisticio, finalmente no se pudo concretar durante estos meses de armisticio pues el presidente Simón Bolívar seguía convencido de que el principio fundamental que debía inspirar este pacto con España era el reconocimiento de Colombia como un Estado libre y soberano. Fallido resultó el intento de los comisionados republicanos que viajaron en mayo de 1821 a las Cortes de Madrid pues pudieron comprobar la nula voluntad del gobierno español de llegar a una negociación conciliatoria ${ }^{117}$. Pero, en cierta medida, el acuerdo marcó un punto de ruptura en la guerra e inclinó ostensiblemente la balanza hacia el bando republicano y finalmente los españoles terminaron reconociendo la causa republicana como un proceso de emancipación nacional, lo cual significó un gran triunfo político que allanó el camino para la victoria militar definitiva ${ }^{118}$.

Aún por encima de los reales efectos del armisticio, no hay que apartar de vista el hecho de que este acuerdo de alguna manera sirvió de precedente para otros esfuerzos conciliatorios como la capitulación misma de la plaza de Cartagena y más tarde la de Pasto en 1822, así como también los armisticios acordados en el Sur, esfuerzos que resultaron realmente fructíferos para mitigar el alto nivel de confrontación política y militar que se venía registrando en esta última fase de la lucha independentista.

\section{FUENTES}

Academia Colombiana de Historia, Bogotá-Colombia. Fondo Archivo del General Miguel de la Torre.

\footnotetext{
${ }^{116}$ Pilar Moreno de Ángel (Comp.), Correspondencia y Documentos, tomo II, 20.

117 Armando Martínez Garnica, La agenda de Colombia 1819-1831 (Bucaramanga: Universidad Industrial de Santander, 2008), 242.

118 Clément Thibaud, República en armas. Los ejércitos bolivarianos en la guerra de Independencia en Colombia y Venezuela (Bogotá: Planeta-Ifea, 2003), 469.
} 
Roger Pita Pico

Archivo General de la Nación (AGN), Bogotá-Colombia. Fondos: Enrique Ortega Ricaurte, Secretaría de Guerra y Marina.

Biblioteca Nacional de Colombia (BNC). Bogotá-Colombia. Fondo Archivo Histórico Restrepo, Fondo I.

\section{BIBLIOGRAFÍA.}

Actas del Congreso de Angostura 1819-1820. Bogotá: Biblioteca de la Presidencia de la República, 1988.

Archivo Santander. Bogotá: Águila Negra Editorial, 1916, tomo VI.

Briceño Perozo, Mario (Comp.). Vida y papeles de Justo Briceño. Caracas: Gráficas Continente, 1970.

Cartas Santander-Bolivar. Bogotá: Biblioteca de la Presidencia de la República, 1988, tomo III.

Corrales, Manuel Ezequiel. Documentos para la historia de la provincia de Cartagena de Indias, tomo 2. Bogotá: Imprenta de Medardo Rivas, 1883.

. Efemérides y Anales del Estado de Bolívar. Bogotá: Casa Editorial de J. J. Pérez, 1889, tomo II.

Correo del Orinoco. Angostura: Impreso por W. B. Stewart, 1821.

Cortázar, Roberto (Comp.). Cartas y Mensajes del General Francisco de Paula Santander. Bogotá: Academia Colombiana de Historia, 1956, Vol. II-III.

. Correspondencia dirigida al General Santander. Bogotá: Academia Colombiana de Historia, 1969, Vol. III, VII.

Cuño Bonito, Justo. Crimen y perdón. El juicio en La Habana al gobernador Gabriel de Torres y Velasco por la entrega de la Plaza de Cartagena (1824-1827). Estudios Ibero-Americanos, 36-2, (2010), 288311.

Mier, José María de. Homenaje a José Padilla en el año del sesquicentenario de la batalla naval de Maracaibo. Bogotá: Editorial Kelly, 1973.

Gazeta de la ciudad de Bogotá. Bogotá: Imprenta del Estado por Nicomedes Lora, 1820-1821. 
Groot, José Manuel. Historia Eclesiástica y Civil de Nueva Granada, tomo III. Bogotá: Imprenta a cargo de Foción Montilla, 1869.

Ibáñez, Roberto. "El Armisticio", en Historia de las Fuerzas Militares de Colombia, ed. Álvaro Valencia Tovar Bogotá: Editorial Planeta, 1993, tomo I [El Ejército],

Lecuna, Vicente (Comp.). Proclamas y discursos del Libertador. Caracas: Lit. y Tip. del Comercio, 1939.

Lemaitre, Eduardo. Historia General de Cartagena. Bogotá: Banco de la República, 1983, tomo III.

LEÓN TELLO, Pilar. El Ejército Expedicionario de Costa Firme: documentos del Conde de Torrepando conservados en el Archivo Histórico Nacional. Madrid: Real Academia de la Historia, 1985, Vol. I.

Martínez Garnica, Armando. La agenda de Colombia 1819-1831. Bucaramanga: Universidad Industrial de Santander, 2008.

; Daniel Gutiérrez Ardila. La contrarrevolución de los pueblos de las Sabanas de Tolú y el Sinú (1812). Bucaramanga: Universidad Industrial de Santander, 2010.

Mercado, Jorge. Campaña de invasión del teniente general don Pablo Morillo 1815-1816. Bogotá: Editorial Iris, 1963.

Moreno De Ángel, Pilar (Comp.), Correspondencia y Documentos del General José María Córdova. Bogotá: Editorial Kelly, 1974, tomo II.

O’Leary, Simón B. Memorias del General O Leary, tomos XVII-XVIII. Caracas: Imprenta de la Gaceta Oficial, 1983.

Órdenes militares del último gobernador español en Cartagena de Indias 1820-1821. Bogotá: Litografía Arco, 1986.

Pérez O., Eduardo. La guerra irregular en la Independencia de la Nueva Granada y Venezuela 18101830. Tunja: UPTC, 1982.

Plazas Olarte, Guillermo. "Historia Militar". En: Historia Extensa de Colombia, Vol. XVIII, tomo III. Bogotá: Ediciones Lerner, 1970. 
Quintero Serpa, Lúmar Hernando. Los Colorados. Los guerrilleros del Rey. Bucaramanga: Sic Editorial, 2009.

Restrepo, José Manuel. Diario político y militar, tomo I. Bogotá: Imprenta Nacional, 1954.

. Documentos importantes para la historia de la Revolución de la República de Colombia en la América Meridional. Medellín: Universidad de Antioquia-Universidad Nacional, 2009, CD.

Historia de la Revolución de la República de Colombia, tomo III. Bogotá: Editorial Besanzon, 1858.

Rodríguez Villa, Antonio. El teniente general don Pablo Morillo. Primer Conde de Cartagena, Marqués de la Fuerte (1778-1837), tomo IV. Madrid: Tipografía de Fortanet, 1910.

Segovia Salas, Rodrigo. 105 días. El Sitio de Pablo Morillo a Cartagena de Indias. Bogotá: El Áncora, 2007.

Sourdís Nájera, Adelaida. "Ruptura del Estado colonial y tránsito hacia la República 1800-1850”. En Historia económica y social del Caribe colombiano. Editado por Adolfo Meisel Roca. Bogotá: Ediciones Uninorte-Ecoe Ediciones, 1994, 155-184.

Thibaud, Clément. República en armas. Los ejércitos bolivarianos en la guerra de Independencia en Colombia y Venezuela. Bogotá: Planeta-Ifea, 2003. 